\title{
Transduction of Selective Recognition of Heavy Metal Ions by Chemically Modified Field Effect Transistors (CHEMFETs)
}

\author{
Peter L. H. M. Cobben, ${ }^{\dagger, \downarrow}$ Richard J. M. Egberink, ${ }^{\dagger}$ Johan G. Bomer, ${ }^{\ddagger}$ Piet Bergveld, ${ }^{\ddagger}$ \\ Willem Verboom, ${ }^{\dagger}$ and David N. Reinhoudt ${ }^{*, \dagger}$ \\ Contribution from the Laboratories of Organic Chemistry and Bioinformatics, University of \\ Twente, P.O. Box 217, 7500 AE Enschede. The Netherlands. Received April 17, 1992. \\ Revised Manuscript Received September 17, 1992
}

\begin{abstract}
Specifically substituted calix[4]arenes that complex selectively silver (2), copper (13), cadmium (23), and lead (29) cations were synthesized via di-and tetraalkylation of p-tert-butylcalix [4]arene. Calix [4] arenes derivatized with thioether thioamide, and dithiocarbamoyl functionalities could be obtained in high overall yields. Integrated on a chemically modified field effect transistor (CHEMFET) the selective complexation of heavy metal ions by these calix [4]arenes is transduced directly into an electrical signal. An architecture for CHEMFETs is used in which a hydrophilic polyHEMA hydrogel is covalently attached between the gate oxide surface of a modified ISFET and the hydrophobic sensing membrane that contains the receptor molecule. CHEMFETs based on the calix [4] arene (2) with two diametrically substituted thioether functionalities responded selectively (60 $\mathrm{mV}$ decade-1) to a change in silver activity in the aqueous solution in the presence of potassium, calcium, cadmium, and copper ions $\left(\log K_{i, j} \leq-4\right)$. The selectivity toward mercury (log $K_{i j}=-2.7$ ) is comparable to the best neutral carrier based ISE so far. The calix[4] arene (13), with four dithiocarbamoyl groups, incorporated in a CHEMFET responsed Nernstian ( $30 \mathrm{mV}$ decade ${ }^{-1}$ ) to a change in copper activity. The calix [4]arene (23), which has four dimethylthiocarbamoylmethoxyethoxy substituents, was selective in a CHEMFET ( $30 \mathrm{mV}$ decade $e^{-1}$ ) toward cadmium in the presence of calcium and potassium ions. Two classes of ionophores can be distinguished for the selective detection of lead(II) cations by CHEMFETs, oxamide and thioamide ionophores, respectively. Tetrasubstitution of the calix [4]arene with thioamide groups (29) is a prerequisite for the selective detection of lead and leads to a highly selective CHEMFET (log $K_{1, j}-3.4$ to -5.2$)$,
\end{abstract}

\section{Introduction}

In supramolecular chemistry the analogy between biological receptors and abiotic synthetic receptor molecules is limited to the first step in the cascade of events that occurs in biological receptors, viz. the selective recognition of a guest species. We are currently investigating a more active role of molecular recognition viz. the subsequent transduction of these molecular rocognition processes into macroscopic properties. A system that has the potential to transfer this molecular recognition into an electrical signal is an ion sensitive field effect transistor (ISFET), an electronic device in a semiconductor chip. ${ }^{1}$ The ISFET (Figure la) consists of two n-type diffusion regions (source and drain) embedded in a p-type silicon substrate (bulk). The conductance in the channel between the source and the drain is a function of the electrical field perpendicular to the gate oxide surface. When the gate oxide contacts an aqueous solution a change of $\mathrm{pH}$ will change the electronic signal as a function of the state of ionization of the amphoteric surface $\mathrm{SiOH}$ groups. Typical pH responses of $\mathrm{SiO}_{2}$ ISFETs are 37-40 mV per decade. 3,4 When an ion-selective membrane is attached to the gate oxide of the ISFET, the developed membrane potential determines the ISFET response. ${ }^{5}$ The extraction ability of the ionophore/ membrane combination determines which ion governs the membrane potential. The selectivities with respect to other cations are given by the potentiometric selectivity coefficient $\left(K_{1, j}\right)$ in the (empirical) Nicolsky-Eisenmann equation $\left(E=E^{\circ}+\left(R T / z_{l} F\right)\right.$ In $\left[a_{1}+K_{1, j} a_{j}^{x / 2 j}\right] ; E$ is the potentiometric response, $E^{\circ}$ the standard potential, $z$ is the charge of ion $i$ or $j$, and $a_{i}$ and $a_{i}$ are the activities of the primary and the interfering ion, respectively), 6.7

However, some serious problems have been recognized of such a modified ISFET (CHEMFET); the membrane is mechanically not stable, the response is influenced by $\mathrm{CO}_{2}$, and most receptor molocules are not sufficiently hydrophobic to give chemically stable systems because they leach out of the membrane to the contacting aqueous solution.

We have designed a novel architecture for CHEMFETs (Figure (b) in order to solve the problems mentioned above. Firstly, the attachment of the membrane was improved by mechanical ${ }^{8}$ or chemical ${ }^{9.10}$ anchoring to the surface of the gate oxide. Secondly,

Laboratory of Organic Chemistry.

Laboratory of Bioinformatics. we have introduced a hydrogel layer (polyHEMA) between the gate oxide and the sensing membrane in which an aqueous buffered solution of salts can be absorbed. "This eliminates the interference of $\mathrm{CO}_{2}$ on the CHEMFET response, and it stabilizes the potential developed in the sensing membrane. 11,12 Plasticized PVC membranes that contain an ionophore are widely used as the sensing membrane, but leakage of plasticizer to the contacting aqueous solution and weak adhesion of the membrane to the ISFET prompted us to develop other polymeric membranes. 9,12

However, in order to study the selectivity of new ionophores CHEMFETs based on plasticized PVC membranes can be used. In this paper the selective recognition of heavy metal ions by specifically substituted calix[4]arenes integrated with chemically modified ion sensitive field effect transistors (CHEMFETs) is described. Previously, we reported highly selective CHEMFETs $^{13,14}$ based on calix[4]arenes that are selective for hard

(1) Reinhoudt, D. N,i Sudhölter, E. J. R. Adv. Mater, 1990, 2, 23-32.

(2) Bergveld, P.; Sibbald, A. Comprehensive Analytical Chemistry, Vol XXIII: Analytical and Biomedical Applications of Ion-Sensitive Field-Effect Transistors; Elsevier; Amsterdam, 1988.

(3) Bousse, L.; Bergveld, P. Sens. Actuators 1984, 6, 65-78.

(4) van den Berg, A.; Bergveld, P.; Reinhoudt, D. N.; Sudhölter, E, J. R Sens. Actuators 1985, 8, 129-148.

(5) Moss, S. D.; Janata, J.; Johnson, C. C. Anal. Chem, 1975, 47 $2238-2243$.

(6) Lewenstam, A.; Hulanicki, A. Seleclive Electrode Rev, 1990, 12, $161-201$.

(7) IUPAC Recommendations for Nomenclature of Ion-Selective Electrodes: Pure Appl. Chem. 1976, 48, 127.

(8) Blackburn, G. F, Janata, J, J. Electrochem. Soc, 1982, 129, $2580-2584$.

(9) van der Wal, P. D,; Skowronska-Ptasinska, M.; van den Berg, A.; Bergveld, P,; Sudhölter, E. J, R.; Reinhoudt, D. N. Anal. Chim. Acta 1990 $231,41-52$.

(10) Harrison, D. J.; Teclemariam, A.; Cunningham, L, Anal, Chem, 1989 $61,246-251$.

(11) Sudhölter, E, J, R.; van der Wal, P. D.; Skowronska-Ptasinska, M. van den Berg, A.; Bergveld, P.; Reinhoudt, D. N. Anal Chim. Acta 1990, 230 $59-65$.

(12) van der Wal, P. D. Ph.D. Thesis, University of Twente, Enschede,

(13) Sudhölter, E. J. R.; van der Wal, P. D.; Skowronska-Ptasinska, M.; van den Berg, A.; Bergveld, P.; Reinhoudt, D. N. Recl. Trav. Chim. Pays-Bas $1990,109,222-225$

(14) Brunink, J. A. J.; Haak, J, R.; Bomer, J, G,; Reinhoudt, D. N. MeKervey, M. A.; Harris, S. J. Anal. Chim. Acta 1991, 254, 75-80. 
Chart I

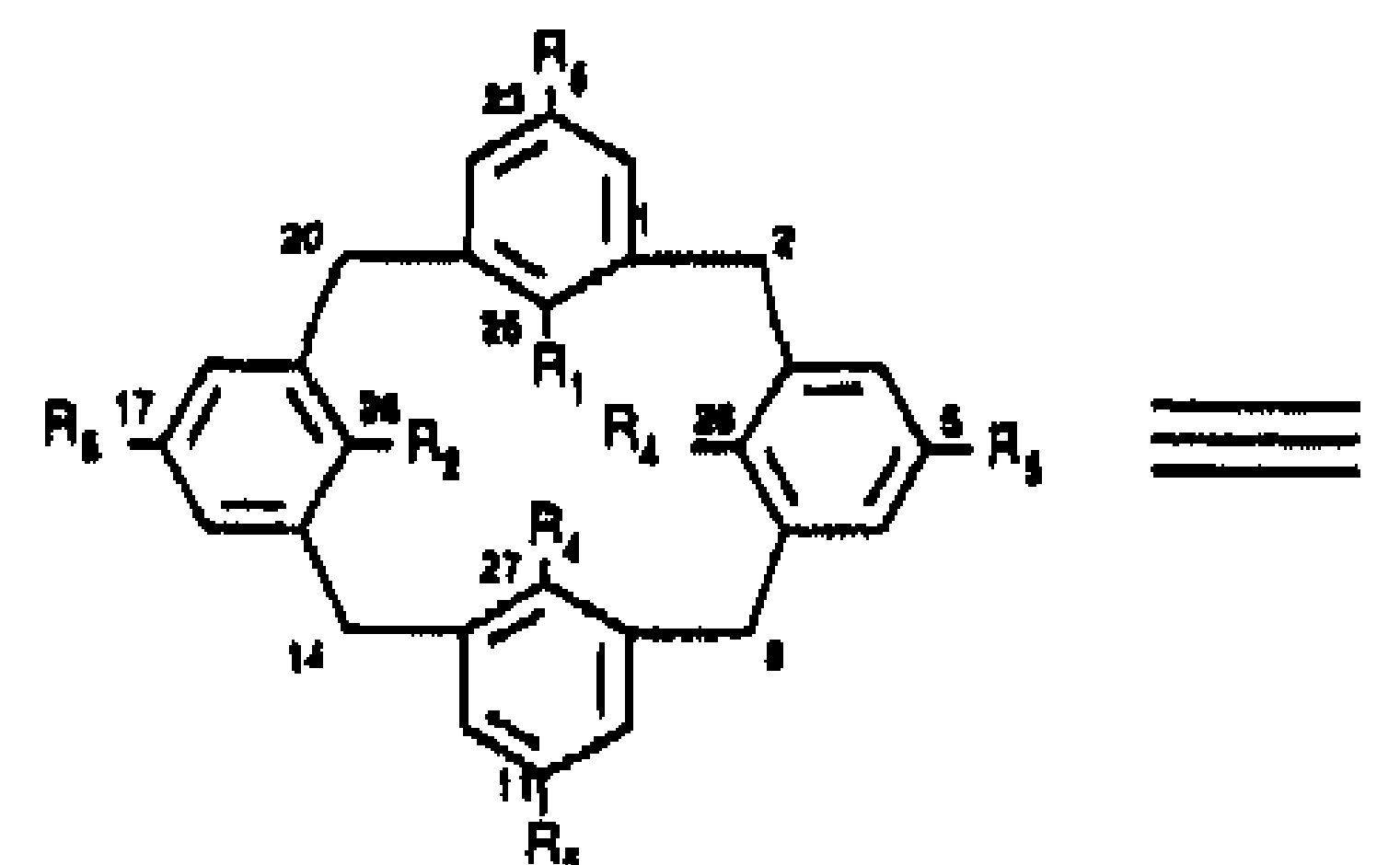

$1 \quad R_{1}=R_{2}=R_{3}=R_{1}=O H, R_{g}=t \cdot B u$

$2 \mathrm{R}_{1}=\mathrm{R}_{3}=\mathrm{OCH}_{2} \mathrm{CH}_{2} \mathrm{SCH}_{3} \mathrm{R}_{2}=\mathrm{R}_{4}=\mathrm{OH}, \mathrm{R}_{5}=1 \cdot \mathrm{Bu}$

$3 \quad R_{1}=R_{2}=R_{3}=R_{4}=O C_{2} C H_{2} S_{C H}, R_{5}=t-B u$

$4 R_{1}=R_{3}=O n-P_{1} R_{2}=R_{4}=O H_{1} R_{5}=t-B u$

$5 \quad R_{1}=R_{3}=O C_{2} C H_{2} S_{C H}, R_{2}=R_{4}=O H \cdot P_{t}, R_{f}=r-B u$

$6 \quad R_{1}-R_{4}=O H, R_{5}=H$

$7 \quad R_{1}=R_{3}=O P(O)\left(O C_{2} H_{3}\right)_{2}, R_{2}=R_{4}=O H_{1} R_{5}=H$

$8 \quad R_{1}=R_{3}=R_{5}=H, R_{2}=R_{4}=O H$

$9 \quad R_{1}=R_{3}=O \mathrm{OCH}_{2} \mathrm{CH}_{2} \mathrm{SCH}_{3}, \mathrm{R}_{2}=\mathrm{R}_{4}=\mathrm{R}_{\mathrm{g}}=\mathrm{H}$

$10 \mathrm{R}_{1}-\mathrm{R}_{4}=O \mathrm{OCH}_{2} \mathrm{C}(\mathrm{O}) \mathrm{OC}_{2} \mathrm{H}_{5}, \mathrm{R}_{5}=r-\mathrm{Bu}$

$11 \mathrm{R}_{1} \cdot \mathrm{R}_{4}=\mathrm{OCH}_{2} \mathrm{CH}_{2} \mathrm{OH}, \mathrm{R}_{\mathrm{g}}=t \cdot \mathrm{Bu}$

$12 \mathrm{R}_{1}-\mathrm{R}_{4}=\mathrm{OCH}_{2} \mathrm{CH}_{2} \mathrm{OTOS}_{1} \mathrm{R}_{5}=t-\mathrm{Bu}$

$13 R_{1} \cdot R_{4}=\mathrm{OCH}_{2} \mathrm{CH}_{2} \mathrm{SC}(\mathrm{S}) \mathrm{N}\left(\mathrm{C}_{2} \mathrm{H}_{3}\right)_{2}, \mathrm{R}_{3}=t-\mathrm{Bu}$

$14 R_{1}=R_{3}=O C_{2} C(O) O C_{2} H_{3}, R_{2}=R_{4}=O_{H-P r}, R_{3}=1-B u$

$15 R_{1}=R_{3}=O \mathrm{CH}_{2} \mathrm{CH}_{2} \mathrm{OH}, R_{2}=R_{4}=O R_{-}-P_{1} R_{5}=r-B U$

cations. ${ }^{15-17}$ The calix[4] arene building block is easily accessible and it gives a high hydrophobicity to a receptor molecule. ${ }^{18}$ Calix [4]arenes are cyclic tetramers of p-tert-butylphenol and formaldehyde. Calix [4]arenes can exist in four different extreme conformations $^{18}$ (cone, partial cone, 1,2-alternate, and 1,3-alternate), but for the research described in this paper the cone conformation is the most important conformer.

In receptor molecules for the softer heavy metal cations sulfur or nitrogen donor atoms are preferred, ${ }^{19}$ but for our purpose nitrogen donor atoms have to be excluded, because these might induce an unfavorable $\mathrm{pH}$ sensitivity of the ultimate sensor. Several sulfur containing functionalities, like thioethers (silver selective), thioamides (cadmium selective), and thiocarbamoyl groups (copper selective), have been used for receptor molecules in ion-selective electrodes, ${ }^{20}$ However, the hydrophobicity of these compounds is rather low for the application in CHEMFETs. ${ }^{2}$ Calix[4]arene based receptor molecules for heavy metal ions offer the possibility of an increased hydrophobicity and a synthetic

(15) (a) Ardulni, A.; Pochini, A.; Reverbi, S,; Ungaro, R. J. Chem. Soc., Chem. Commun. 1984, 981 1-982. (b) Ungaro, R.; Pochini, A.; Andreett, $G$. D. J. Inclusion Phenom. Mol. Recognit. Chem. 1984, 2, 199-206. (c) Arduini D. J Inclusion Phenom. Mol. Recognit. Chem. 1984, 2, 199-206, (c) Arduini, A.; Pochini, A.i Reverbi, S.i Ungaro, R,i Andreetti, G. D.i Ugozzoli, F.
Tetrahedron 1986, 42, 2089-2100. (d) McKervey, M. A.: Seward, E. M.; Tetrahedron 1986, 42, 2089-2100, (d) McKervey, M. A.: Seward, E. M.; Ferguson, G.; Ruhl, B.; Harris, S. J. J. Chem. Soc., Chem. Commun. 1985,
388-390. (c) Arnaud-Neu, F.; Collins, E. M.; Deasy, M.i Ferguson, G.; 388-390. (e) Arnaud-Neu, F.; Collins, E. M.; Deasy, M.; Ferguson, G.;
Harris, S. J.; Kaitner, B.; Lough, A. J.; McKervey, M. A,; Marques, E.; Ruhi Harris, S. J.; Kaitner, B.; Lough, A. J.; McKervey, M. A,; Marques, E.; Ruhl,
B. L.i Schwing-Weill, M. J., Seward, E. M. J. Am. Chem. Soc. 1989, III B. L.i Schwing-Weill, M. J.; Seward, E. M. J. Am. Chem. Soc. 1989, IIl,
$8681-8691$. (I) Chang, S.-K.; Cho, I. J. Chem. Soc. Perkin Trans, / 1986, 211-214. (g) Calestant, G.; Ugozzoli, F.; Arduini, A.; Ghidini, E.; Ungaro, R. J. Chem. Soc. Chem, Commun, 1987, 344-346. (h) Ferguson, G.; Kaitner, B.; McKervey, M. A.; Seward, E. M. J. Chem. Soc., Chem. Commun. 1987 $584-585$.

(16) (a) Alfieri, C.; Pradi, E.; Pochini, A.; Ungaro, R,; Andreetti, G. D. J. Chem. Soc., Chem. Commun, 1983, 1075-1077. (b) Ghidini, E,; Ugozzoli, F; Ungaro, R.; Harkema, S.; El-Fadl, A. A.; Reinhoudt, D. N. J. Am. Chem. Soc. $1990,112,6979-6985$.

(17) (a) Reinhoudt, D. N.i Dijkstra, P. J.; in't Veld, P. J. A.; Bugge, K.-E.; Harkema, S, Ungaro, R.; Ghidini, E. J. Am. Chem. Soc, 1987, 109, 4761-4762. (b) Dijkstra, P. J.; Brunink, J, A. J.; Bugge, K.-E.; Reinhoudt, D. N.; Harkema, S.; Ungaro, R.; Ugozzoli, F; Ghidini, E. J. Am. Chem. Soc. 1989, III, 7567-7575.

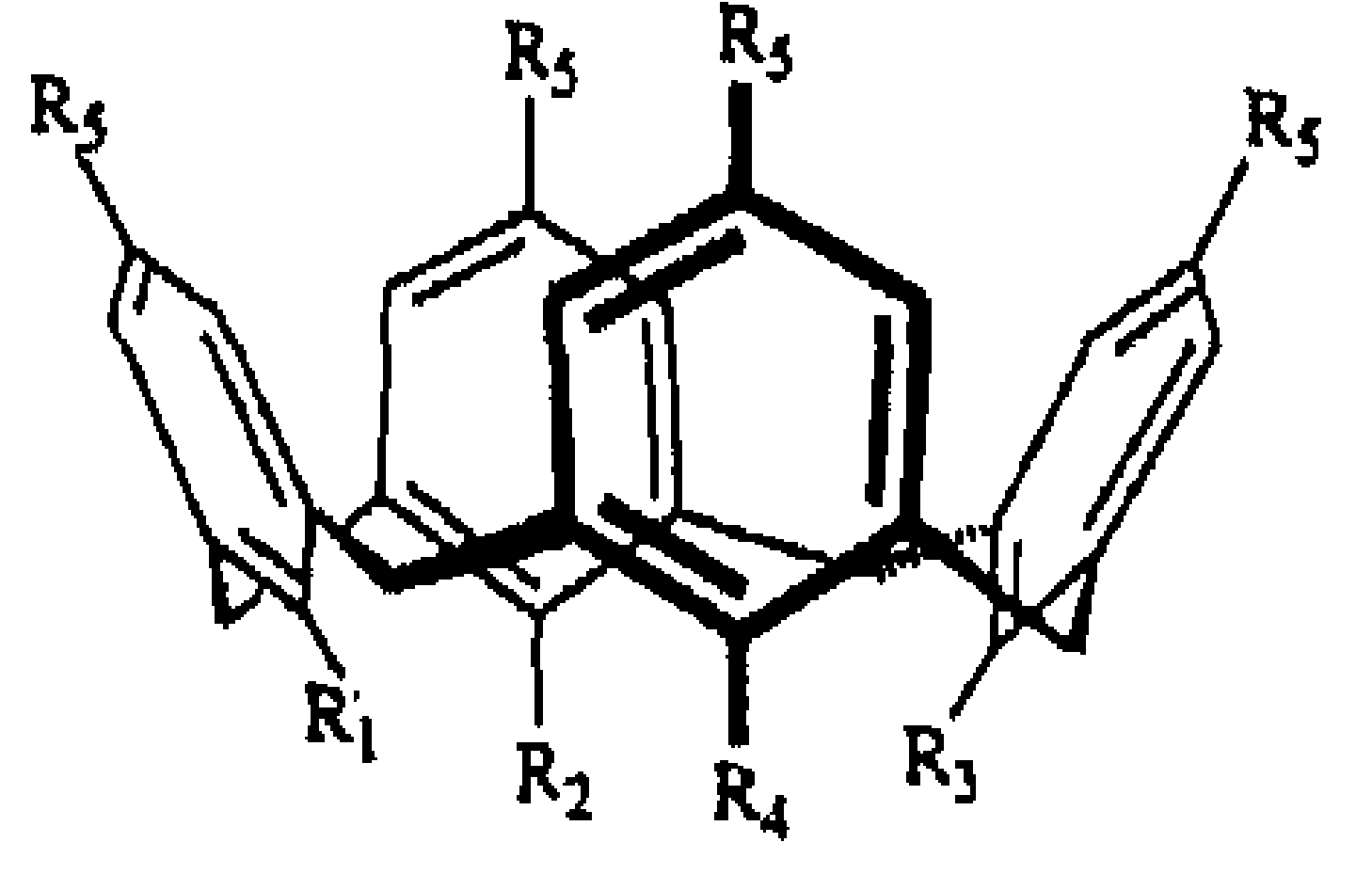

Chart 1

16 $R_{1}=R_{3}=O C_{2} C H_{2} O T O S, R_{2}=R_{4}=O n-P r, R_{5}=8-B u$

$17 \mathrm{R}_{1}=\mathrm{R}_{3}=O \mathrm{OCH}_{2} \mathrm{CH}_{2} \mathrm{SC}(\mathrm{S}) \mathrm{N}\left(\mathrm{C}_{2} \mathrm{H}_{5}\right)_{2}, \mathrm{R}_{2}=\mathrm{R}_{4}=\mathrm{On}-\mathrm{Pr}, \mathrm{R}_{5}=r \cdot \mathrm{Bu}$

$18 \mathrm{R}_{1}=\mathrm{R}_{3}=O \mathrm{OH}_{2} \mathrm{C}(\mathrm{O}) \mathrm{N}\left(\mathrm{CH}_{3}\right)_{2}, \mathrm{R}_{2}=\mathrm{R}_{4}=\mathrm{OH}, \mathrm{R}_{5}=t \cdot \mathrm{Bu}$

$19 R_{1}=R_{3}=O C_{2} \mathrm{C}(\mathrm{S}) \mathrm{N}\left(\mathrm{CH}_{3}\right)_{2}, \mathrm{R}_{2}=\mathrm{R}_{4}=\mathrm{OH}, \mathrm{R}_{5}=t \cdot \mathrm{Bu}$

$20 R_{1}=R_{2}=O C H_{2} C(O) N\left(C_{3}\right)_{2}, R_{3}=R_{4}=O H_{1} R_{3}=r-B u$

$21 \mathrm{R}_{1}=\mathrm{R}_{2}=\mathrm{OCH}_{2} \mathrm{C}(\mathrm{S}) \mathrm{N}\left(\mathrm{CH}_{3}\right)_{2}, \mathrm{R}_{3}=\mathrm{R}_{4}=\mathrm{OH}, \mathrm{R}_{5}=t \cdot \mathrm{Bu}$

$22 \mathrm{R}_{1}-\mathrm{R}_{4}=\mathrm{OCH}_{2} \mathrm{CH}_{2} \mathrm{OCH} \mathrm{CH}_{2} \mathrm{C}(\mathrm{O}) \mathrm{N}\left(\mathrm{CH}_{3}\right)_{2}, \mathrm{R}_{5}=t-\mathrm{Bu}$

$23 \mathrm{R}_{1}-\mathrm{R}_{4}=\mathrm{OCH}_{2} \mathrm{CH}_{2} \mathrm{OCH}_{2} \mathrm{C}(\mathrm{S}) \mathrm{N}\left(\mathrm{CH}_{3}\right)_{2}, \mathrm{R}_{9}=1-\mathrm{Bu}$

24 $\mathrm{R}_{1}=\mathrm{R}_{3}=\mathrm{OCH}_{2} \mathrm{CH}_{2} \mathrm{OCH}_{2} \mathrm{C}(\mathrm{O}) \mathrm{N}\left(\mathrm{CH}_{3}\right)_{2}, \mathrm{R}_{2}=\mathrm{R}_{1}=\mathrm{O}-\mathrm{Pr}_{1} \mathrm{R}_{5}=t \cdot \mathrm{Bu}$

$25 \quad \mathrm{R}_{1}=\mathrm{R}_{3}=O \mathrm{CH}_{2} \mathrm{CH}_{2} \mathrm{OCH}_{2} \mathrm{C}(\mathrm{S}) \mathrm{N}\left(\mathrm{CH}_{3}\right)_{2}, \mathrm{R}_{2}=\mathrm{R}_{4}=\mathrm{On}-\mathrm{Pr}_{1} \mathrm{R}_{5}=t-\mathrm{Bu}$

$26 \mathrm{R}_{1}=\mathrm{R}_{3}=\mathrm{OCH}_{2} \mathrm{C}(\mathrm{O}) \mathrm{N}\left(\mathrm{CH}_{3}\right)_{2}, \mathrm{R}_{2}=\mathrm{R}_{4}=\mathrm{On}-\mathrm{Pr}_{1} \mathrm{R}_{5}=t-\mathrm{Bu}$

$27 R_{1}=R_{3}=O C_{2} C(S) N\left(C_{3}\right)_{21} R_{2}=R_{4}=O n-P T, R_{5}=t-B u$

$28 \mathrm{R}_{1}-\mathrm{R}_{4}=\mathrm{OCH}_{2} \mathrm{C}(\mathrm{O}) \mathrm{N}\left(\mathrm{CH}_{3}\right)_{2}, \mathrm{R}_{5}=\mathrm{r} \cdot \mathrm{Bu}$

$29 \mathrm{R}_{1}-\mathrm{R}_{4}=\mathrm{OCH}_{2} \mathrm{C}(\mathrm{S}) \mathrm{N}\left(\mathrm{CH}_{3}\right)_{2}, \mathrm{R}_{5}=1-\mathrm{Bu}$

building block for the positioning of the coordination sites in one molecule.

\section{Results and Discussion}

Synthesis of Receptor Molecules. For the complexation of silver, calix [4]arene was derivatized in various ways with a thioether functionality. Reaction of p-tert-butylcalix[4]arene 1 with 3 equiv of 2-chloroethyl methyl sulfide in the presence of 1 equiv of $\mathrm{K}_{2} \mathrm{CO}_{3}{ }^{22}$ in refluxing acetonitrile afforded the diametrically substituted bis[2-(methylthio)ethoxy]calix [4]arene 2 in $67 \%$ yield. The formation of 2 clearly followed from its symmetrical ${ }^{1} \mathrm{H}$ NMR spectrum showing among others a typical $A B$ pattern at $\delta 4,31$ and 3.32 for the methylene bridge protons $(J=13.1 \mathrm{~Hz})$. The tetrasubstituted calix [4]arene 3 could be obtained by reaction of disubstituted calix [4]arene 2 with excess 2-chloroethyl methy] sulfide in $\mathrm{NaH} / \mathrm{DMF}$ in $61 \% .23$ The characteristic AB pattern at $\delta 4.38$ and $3.15(J=12.7 \mathrm{~Hz})$ for the methylene bridge protons and the typical value 24 of $\delta 31.1$ for the corresponding carbon absorption indicate the cone conformation of 3 . The synthesis of a receptor molecule with two pairs of diametrically located different substituents was performed starting from the previously described ${ }^{25} 26,28$-dipropoxycalix [4]arene 4. Analogously to the formation of 3 , reaction of 4 with excess 2 -chloroethyl methyl sulfide in $\mathrm{NaH} / \mathrm{DMF}$ gave 25,27-bis[2-(methylthio)ethoxy]26,28-dipropoxycalix [4]arene 5 in the cone conformation in $61 \%$ yield. In order to prepare an ionophore with increased flexibility the selectively dehydroxylated calix [4]arene 8 was reacted with excess 2-chloroethyl methyl sulfide in $\mathrm{NaH} / \mathrm{DMF}$ to give the

(18) (a) Gutsche, C. D. Callxarenes, Monographs in Supramolecular Chemistry; Stoddart, J. F, Ed,; The Royal Sociely of Chemistry: Cambridge, 1989; Vol. 1. (b) Calixarenes: A Versatile Class of Macrocyclic Compounds: topics in inclusion science; Vicens, J., Böhmer, V. Eds.; Kluwer Academic Press: Dordrecht, 1991; Vol. 3 .

(19) Bruening, R. L.; Izatt, R. M.; Bradshaw, J. S. In Cation Binding by Macrocycles; Inoue, Y, Gokel, G. W., Eds.; M. Dekker Ine: New York, 1990; $\mathrm{pp} 111-132$.

(20) CRC Press Handbook of lon-Selective Electrodes: Selectivity Coefficients; Umezawa, Y, Ed,; CRC Press Inc.: FL, 1990

(21) Dinten, O.; Spichiger, U. E,; Chaniotakis, N.; Gehrig, P.; Rusterholz B.; Morf, W. E.i Simon, W. Anal. Chem. 1991, 63, 596-603. 


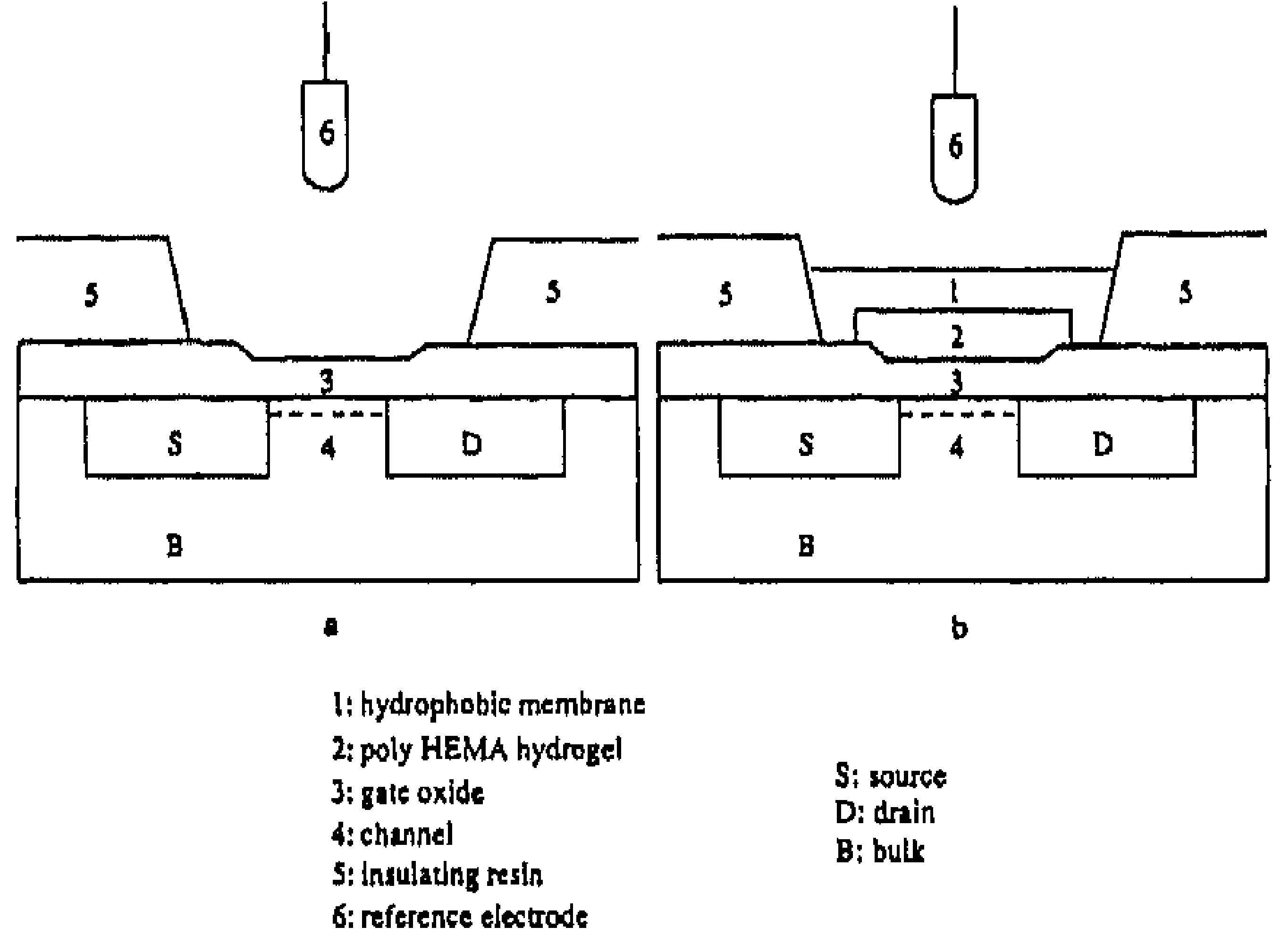

Flgure 1. Schematic representation of (a) an ISFET and (b) a CHEMFET.

25,27-bis[2-(methylthio)ethoxy]calix[4]arene 9 in 57\% yield. Compound 8 was prepared in $74 \%$ overall yield by reaction of de-tert-butylated calix[4]arene 6 with 3 equiv of diethyl chlorophosphate in $\mathrm{CH}_{3} \mathrm{CN}$ in the presence of $\mathrm{K}_{2} \mathrm{CO}_{3}$ as a base and subsequent treatment of the diametrically diphosphorylated calix [4]arene 7 formed with potassium in liquid ammonia at -33 - $\mathrm{C}$ analogously as described for the corresponding tert-butyl analogues. 26

The first target molecule for the complexation of copper (13) contains four thiocarbamoyl groups at one face of the calix [4]arene moiety (i.e., the calix [4]arene is in the cone conformation). The synthesis starts from the know tetraester ${ }^{27} 10$ which upon reduction with $\mathrm{LiAlH}_{4}$ in $\mathrm{Et}_{2} \mathrm{O}$ at room temperature gave 11 in $86 \%$ yield. Reaction of 11 with p-toluenesulfonyl chloride in pyridine at 0 ${ }^{\circ} \mathrm{C}$ gave the tetratosylate 12 which was reacted with the sodium salt of $N, N$-diethyldithiocarbamic acid in acetone to give the target tetrakis(thiocarbamoyl)calix [4]arene 13 in $72 \%$ yield. Throughout the whole reaction sequence the original cone conformation of 10 was retained as followed from the characteristic $\mathrm{AB}$ pattern at $\delta 4.53$ and $3.18(J=12.7 \mathrm{~Hz})$ for the methylene bridge protons in the 'H NMR spectrum of 13 and the typical value ${ }^{24}$ of $\delta 31.4$ for the corresponding carbon atoms in the ${ }^{13} \mathrm{C}$ NMR spectrum. In addition to a satisfactory FAB mass spectrum and elemental analysis the structure of 13 was confirmed by its NMR spectra. The 'H NMR spectrum exhibits among others a singlet at $\delta 6.77$ for the aromatic hydrogens, a triplet at $\delta 4.26(J=6.7 \mathrm{~Hz})$ for the $\mathrm{ArOCH}_{2}$ protons, a quartet at $\delta 3.76(8 \mathrm{H})$ for part of the $\mathrm{NCH}_{2}$ groups (the other eight H's coincide with a multiplet of other $\mathrm{CH}_{2}$ signals), and a singlet at $\delta 1.07$ for the tert-butyl groups. Charactcristic absorptions in the ${ }^{13} \mathrm{C}$ NMR spectrum are $\delta 195.5$ $(\mathrm{C}=\mathrm{S}), \delta 73.4\left(\mathrm{ArOCH}_{2}\right)$, two signals due to hindered rotation, at $\delta 49.5$ and 46.8 for the $\mathrm{NCH}_{2}$ moieties, and $\delta 36.6\left(\mathrm{CH}_{2} \mathrm{~S}\right)$. In the second target molecule 17 the calix[4]arene skeleton is, in addition to two propoxy groups, only functionalized with two thiocarbamoyl groups. In this case the synthesis starts from the diametrically substituted 26,28 -dipropoxycalix [ 4 ]arene $e^{25} 4$ which was reacted with excess ethyl bromoacetate in NaH/DMF at 60

(22) van Loon, J.-D.; Arduini, A.; Coppi, L,i Verboom, W.; Pochini, A.; Ungaro, R.; Harkema, S.; Reinhoudt, D, N. J. Org, Chem. 1990, 5s, $5639-5646$.

(23) The tetrasubstituted calix[4]arene 3 could also be obtained by direct reaction of p-tert-butylcalix [4]arene with excess 2-chloroethyl methyl sulinde, but purification was more difficult and the yield lower.

(24) Jaime, C,; de Mendoza, J.; Prados, P.; Nieto, P. M.; Sanchez, C. J. Org. Chem. 1991, 56, 3372-3376.

(25) Itwamoto, K.; Araki, K.; Shinkai, S. Tetrahedron 1991, 47, $4325-4342$

(26) Ting, Y.; Verboom, W.; Groenen, L. C.; van Loon, J.-D.; Reinhoude, D. N. J. Chem. Soc, Chem. Commun. 1990, 1432-1433.

(27) Arnaud-Neu, F.; Collins, E. M,; Deasy, M.; Ferguson, G.; Harris, S. J.i Kaitner, B.; Lough, A. J.; McKervey, M. A.; Marques, E.; Ruhl, B. L.; Schwing-Weill, M. J.; Seward, E. M. J. Am. Chem. Soc, 1989, III, $8681-8691$.
${ }^{\circ} \mathrm{C}$ to give 14 in $84 \%$ yield. The cone conformation of 14 followed from the typical absorptions (vide supra) in both the 'H NMR and ${ }^{13} \mathrm{C}$ NMR spectrum. In a similar way as described for 13 receptor molecule 17 could be prepared starting from 14.

For the complexation of cadmium, calix[4]arene was used as a molecular platform to organize two or four thioamide moieties in the same molecule. Reaction of p-tert-butylcalix[4]arene 1 with 2.2 equiv of $N, N$-dimethyl 2-chloroacetamide using 1 equiv of $\mathrm{K}_{2} \mathrm{CO}_{3}$ in $\mathrm{CH}_{3} \mathrm{CN}$ afforded the diametrically dialkylated calix[4]arene 18 in $87 \%$ yield which, upon treatment with Lawesson's reagen ${ }^{28}$ in toluene, gave the corresponding 26,28-bis(thiosmide) 19 in $73 \%$ yield. The 26,28 -functionalization followed from the 'H NMR spectrum of 19 with a characteristic $A B$ pattern for the methylene bridge protons at $\delta 4.25$ and $3.33(J=13.2 \mathrm{~Hz})$ and the introduction of sulfur from the FAB mass spectrum and a typical thione absorption at $\delta 195.6$ in the ${ }^{13} \mathrm{C}$ NMR spectrum. The 27,28-bis(thioamide) 21 could be obtained by reaction of 1 with 2.2 equiv of $N, N$-dimethyl 2-chloroacetamide in the presence of 4.2 equiv of $\mathrm{NaH}$ in DMF at $60^{\circ} \mathrm{C}$ to afford the proximally difunctionalized calix [4]arene 20 in $44 \%$ yield and subsequent treatment with Lawesson's reagent in toluene to give 21 in $90 \%$ yield. Very characteristic for proximal functionalization ${ }^{29}$ are in the ${ }^{1} \mathrm{H}$ NMR spectrum of 21 the three AX signals for the methylene protons at $\delta 4.73,4.55$, and $4.26\left(1: 2: 1 \mathrm{H}_{2 x}\right)$ and at $\delta 3.47,3.38$, and $3.33\left(1: 1: 2 \mathrm{H}_{\mathrm{eq}}\right)$. Subsequently, attention was focussed on calix[4]arenes having $\mathrm{OCH}_{2} \mathrm{CH}_{2} \mathrm{OCH}_{2} \mathrm{C}(\mathrm{S}) \mathrm{NR}_{2}$ substituents, the unit also present in the cadmium ionophore $N, N, N^{\prime}, N^{\prime}$-tetrabutyl-3,6-dioxaoctanedithioamide. ${ }^{30}$ Reaction of tetrakis(hydroxyethoxy)calix [4]arene 11 (cone conformation) with $N, N$-dimethyl 2-chloroacetamide using $\mathrm{NaH}$ as a base in DMF gave the tetrasubstituted compound 22 in $86 \%$ yield which was converted into the corresponding tetrakis(thioamide) 23 in $48 \%$ yield upon treatment with Lawesson's reagent. The original cone conformation was retained in 23 as was clearly indicated in the ${ }^{1} \mathrm{H}$ NMR spectrum by the typical AB pattern of $\delta 4.39$ and $3.11(J=12.6 \mathrm{~Hz})$ for the methylene bridge protons and the characteristic value ${ }^{24}$ of $\delta 31.2$ for the corresponding carbon absorption in the ${ }^{13} \mathrm{C}$ NMR spectrum. In an analogous way ionophore 25 containing two $\mathrm{OCH}_{2} \mathrm{CH}_{2} \mathrm{OCH}_{2} \mathrm{C}(\mathrm{S}) \mathrm{NR}_{2}$ moieties and two propoxy groups was prepared in $52 \%$ yield starting from 25,27-bis(hydroxyethoxy)-26,28-dipropoxycalix[4]arene 15 (cone conformation)

Finally, functionalized calix[4]arenes for the selective complexation of lead were prepared, 26,28-Dipropoxycalix[4]arene ${ }^{25}$ 4 was reacted with 4 equiv of $N, N$-dimethyl 2-chloroacetamide using $\mathrm{NaH} / \mathrm{DMF}$ to give the ionophore 26 in $56 \%$ yield. In the 'H NMR spectrum the characteristic AB pattern at $\delta 4.53$ and $3.17(J=12.7 \mathrm{~Hz})$ for the methylene bridge protons and in the ${ }^{13} \mathrm{C}$ NMR spectrum ${ }^{24}$ the value of $\delta 31.4$ for the corresponding carbon absorption prove the cone conformation of 26 . Treatmen of 26 with Lawesson's reagent in toluene at $85-90^{\circ} \mathrm{C}$ afforded the corresponding thioamide 27 in $82 \%$ yield. In a similar way calix[4]arene 29 was synthesized in $83 \%$ yield starting from compound $28 .{ }^{31}$

Silver Selective CHEMFETs. In order to compare the selectivity coefficients of silver selective CHEMFETs based on the different synthesized ionophores $(2,3,5$, and 9), PVC/DOS (=bis 2 . ethylhexyl)sebacate) membranes were used in which, besides the ionophore, a small amount of potassium tetrakis(4-chloro-

(28) Schelbye, S.; Pederson, B. S.; Lawesson, S.-O. Bull. Soc. Chim. Belg $1978,87,229-238$

(29) Groenen, L. C.; Ruël, B. H. M.; Casnati, A.; Timmerman, P.; Verboom, W.; Harkema, S.: Pochini, A.; Ungaro, R.; Reinhoudt, D. N. Tetro. hedron Lett, 1991, 32, 2675-2678.

(30) Schneider, J. K.; Hofstetter, P.; Pretsch, E.; Ammann, D.; Simon, W Helv. Chim. Acla 1980, 63, 217-224.

(31) (a) McKervey, M. A.; Seward, E. M.; Ferguson, G.; Ruhl, B. L.; Harris, S. J. J. Chem. Soc, Chem. Commun. 1985, 388-390. (b) Chang, S K.; Cho, I. J. Chem. Soc., Perkin Trans. I 1986, 211-214. (c) Ferguson, G.i Kaitner, B.; McKervey, M. A.; Seward, E. M. J. Chem. Soc., Chem. Commun. 1987, 584-585. (d) Arduini, A.; Ghidini, E.; Pochini, A.; Ungaro, R.; Andreetti, G. D.; Calestani, G.: Ugozzoli, F. J. Inclusion Phenom. 1988, 6 . 119-134. 
Table I. Selectivity Data of $\mathrm{Ag}^{+}$Selective CHEMFETs Containing Different Calix[4]arene Ionophores $(2,3,5$, or 9) in the Presence of Different Interfering Nitrate Salts ${ }^{a}$

\begin{tabular}{|c|c|c|c|c|c|c|c|}
\hline \multirow[b]{2}{*}{ entry } & \multirow[b]{2}{*}{ ionophore } & \multicolumn{6}{|c|}{ interfering ions } \\
\hline & & $\begin{array}{l}\mathrm{KNO}_{3} \\
(1 \mathrm{M})\end{array}$ & $\begin{array}{l}\mathrm{Ca}\left(\mathrm{NO}_{3}\right)_{2} \\
(0.1 \mathrm{M})\end{array}$ & $\begin{array}{l}\overline{\mathrm{Cd}\left(\mathrm{NO}_{3}\right)_{2}} \\
(0.1 \mathrm{M})^{2}\end{array}$ & $\begin{array}{l}\overline{\mathrm{Cu}\left(\mathrm{NO}_{3}\right)_{2}} \\
(0.1 \mathrm{M})\end{array}$ & $\begin{array}{c}\mathrm{HNO}_{3} \\
\mathrm{pH}=2.5\end{array}$ & $\begin{array}{c}\mathrm{Hg}\left(\mathrm{NO}_{3}\right)_{2} \\
1 \mathrm{e}-4(\mathrm{pH}=2.5)\end{array}$ \\
\hline 1 & none ${ }^{b}$ & $\bar{c}$ & $\begin{array}{l}-2.7^{d} \\
(49 \mathrm{mV})\end{array}$ & $\begin{array}{l}-2.7^{d} \\
(48 \mathrm{mV})\end{array}$ & $\begin{array}{l}-2.7^{d} \\
(44 \mathrm{mV})\end{array}$ & $\bar{c}$ & $c$ \\
\hline 2 & 2 & $\begin{array}{l}-4.6 \\
(61 \mathrm{mV})\end{array}$ & $\begin{array}{l}-4.1 \\
(59 \mathrm{mV})\end{array}$ & $\begin{array}{l}-4.2 \\
(56 \mathrm{mV})\end{array}$ & $\begin{array}{l}-4.3 \\
(56 \mathrm{mV})\end{array}$ & $\begin{array}{l}-2.4 \\
(58 \mathrm{mV})\end{array}$ & $\begin{array}{l}-2.7 \\
(58 \mathrm{mV})\end{array}$ \\
\hline 3 & 3 & $\begin{array}{l}-4.6 \\
(41 \mathrm{mV})\end{array}$ & $\begin{array}{l}-4.2 \\
(52 \mathrm{mV})\end{array}$ & $\begin{array}{l}-3.9 \\
(48 \mathrm{mV})\end{array}$ & $\begin{array}{l}-4.0 \\
(47 \mathrm{mV})\end{array}$ & $\begin{array}{l}-2.2 \\
(58 \mathrm{mV})\end{array}$ & $\begin{array}{l}-2.3 \\
(51 \mathrm{mV})\end{array}$ \\
\hline 4 & 5 & $\begin{array}{l}-4.7 \\
(55 \mathrm{mV})\end{array}$ & $\begin{array}{l}-4.2 \\
(54 \mathrm{mV})\end{array}$ & $\begin{array}{l}-4.3 \\
(56 \mathrm{mV})\end{array}$ & $\begin{array}{l}-4.4 \\
(53 \mathrm{mV})\end{array}$ & $\begin{array}{l}-2.5 \\
(59 \mathrm{mV})\end{array}$ & $\begin{array}{l}-2.7 \\
(58 \mathrm{mV})\end{array}$ \\
\hline 5 & 9 & $\begin{array}{l}-4.7 \\
(55 \mathrm{mV})\end{array}$ & $\begin{array}{l}-4.5 \\
(56 \mathrm{mV})\end{array}$ & $\begin{array}{l}-4.2 \\
(56 \mathrm{mV})\end{array}$ & $\begin{array}{l}-4.2 \\
(55 \mathrm{mV})\end{array}$ & $\begin{array}{l}-2.3 \\
(58 \mathrm{mV})\end{array}$ & $\begin{array}{l}-2.1 \\
(57 \mathrm{mV})\end{array}$ \\
\hline
\end{tabular}

${ }^{\circ} \mathrm{PVC} / \mathrm{DOS} \approx 1: 20.6-0.8 \mathrm{wt} \% \mathrm{KTCPB} 2(2,3$, and 5$)$ or $1(9) \mathrm{wt} \%$ ionophore, ${ }^{b}$ Not present. 'No cation response. ${ }^{d} 0.01 \mathrm{M}$ interfering salt concentration.

Table II. Selectivity Data of $\mathrm{Cu}^{2+}$ Selective CHEMFETs Containing Different Ionophores (13 or 17) in the Presence of Diffetent Interfering Chloride Salts

\begin{tabular}{|c|c|c|c|c|c|c|}
\hline \multirow[b]{2}{*}{ entry } & \multirow[b]{2}{*}{ ionophore } & \multirow[b]{2}{*}{ membrane } & \multicolumn{4}{|c|}{ interfering ions } \\
\hline & & & $\begin{array}{c}\mathrm{CaCl}_{2} \\
(0.01 \mathrm{M})\end{array}$ & $\begin{array}{c}\mathrm{KCl} \\
(0.1 \mathrm{M})\end{array}$ & $\begin{array}{c}\mathrm{CdCl}_{2} \\
(0.01 \mathrm{M})\end{array}$ & $\begin{array}{c}\mathrm{PbCl}_{2} \\
(0.01 \mathrm{M})\end{array}$ \\
\hline 1 & $\begin{array}{l}13 \\
(2.6 w t \%)\end{array}$ & $\begin{array}{l}\text { PVC/DOP } \\
(1: 2) \\
\text { KTCPB }(1.4 \text { wt\%) }\end{array}$ & $\begin{array}{l}-1.7 \\
(31 \mathrm{mV})\end{array}$ & $a$ & $\begin{array}{l}-2.0 \\
(31 \mathrm{mV})\end{array}$ & $\frac{-1.6}{(31 \mathrm{mV})}$ \\
\hline 2 & $\begin{array}{l}17 \\
(9.2 w+\%)\end{array}$ & $\begin{array}{l}\text { PVC/0-NPOE } \\
(1 ; 1) \\
\text { KTCPB }(0.9 w t \%)\end{array}$ & $\begin{array}{l}-1.9 \\
(59 \mathrm{mV})\end{array}$ & $a$ & $\begin{array}{l}-2.1 \\
(58 \mathrm{mV})\end{array}$ & ${ }^{-1.7}(54 \mathrm{mV})$ \\
\hline
\end{tabular}

"No cation response.

phenyl) borate was incorporated. The polyHEMA hydrogel of the CHEMFET was conditioned with 0.01 molar silver nitrate (HNO , $\mathrm{pH}=4$ ) prior to membrane deposition. First a CHEMFET $^{32}$ was tested without any ionophore present. Such a tetrakis (4-chlorophenyl)borate containing membrane is already silver selective in the case of divalent interfering cations, e.g., calcium, cadmium, and copper $\left(\log K_{\mathrm{i},}=-2.7\right.$, Table I, entry 1) The slope of these responses is less than Nernstian (ca. $45 \mathrm{mV}$ decade ${ }^{-1}$ ). In the case of the monovalent interfering ions no response could be measured at all (Table I, entry 1). This measurement indicates that without ionophore the selectivity is related to the hydration energy.

All the CHEMFETs based on the calix [4]arene ionophores (2 3,5 , and 9) showed a good response toward silver. In general the slopes are Nernstian (55-60 mV decade ${ }^{-1}$, Figure 2) except for the calix [4]arene 3 which exhibits at the high concentrations $(0.1 \mathrm{M})$ of the interfering ions (calcium, cadmium, and copper), a somewhat lower slope of around $50 \mathrm{mV}$ decade ${ }^{-1}$.

The slope is even lower ( $41 \mathrm{mV}$ decade ${ }^{-1}$ ) with $(1 \mathrm{M})$ potassium nitrate (Table $I$, entry 3 ) as the interfering salt. The selectivities toward cations like potassium, calcium, cadmium, and copper for these calix [4]arenes are between $8 \times 10^{3}$ and $50 \times 10^{3}$. The selectivity toward silver versus potassium is the highest $\left(\log K_{\mathrm{AB}, \mathrm{K}}\right.$ $= \pm-4,7$ ) and nearly identical for all compounds of Table 1

The dehydroxylated calix [4] arene 9 shows a higher selectivity toward calcium $\left(\log K_{\mathrm{ij}}=-4.5\right)$ than the calix [4]arenes 2,3 , and 5 with four (calcium coordinating) oxygen atoms ( $\log K_{i, j}=\mathrm{ca}$. -4.2). A similar result was found with the heavy metal ions cadmium and copper as the interfering ions, although the effect is less pronounced. The calix [4]arene 3 with the four soft sulfur donor sites showed for both interfering ions the highest interference $\left(\log K_{i,}=\right.$ ca. -3.9$)$. The other three calix [4]arenes $(2,5$, and 9) are more selective to silver. The selectivity coefficients (log $\left.K_{1,}\right)$ in nitric acid $(\mathrm{pH}=2.5)$ are between -2.2 and -2.5 . The interference of mercury is most severe, but still a selective response was found, ${ }^{33}$ The selectivities of the two disubstituted calix-

(32) Interfering cations are chosen as representative for a group of alkal (potassium) or alkaline earth metal (calcium) cations. Other heavy meta interfering cations are taken into account because of their specific interference or a particular ion-selective electrode. ${ }^{20}$

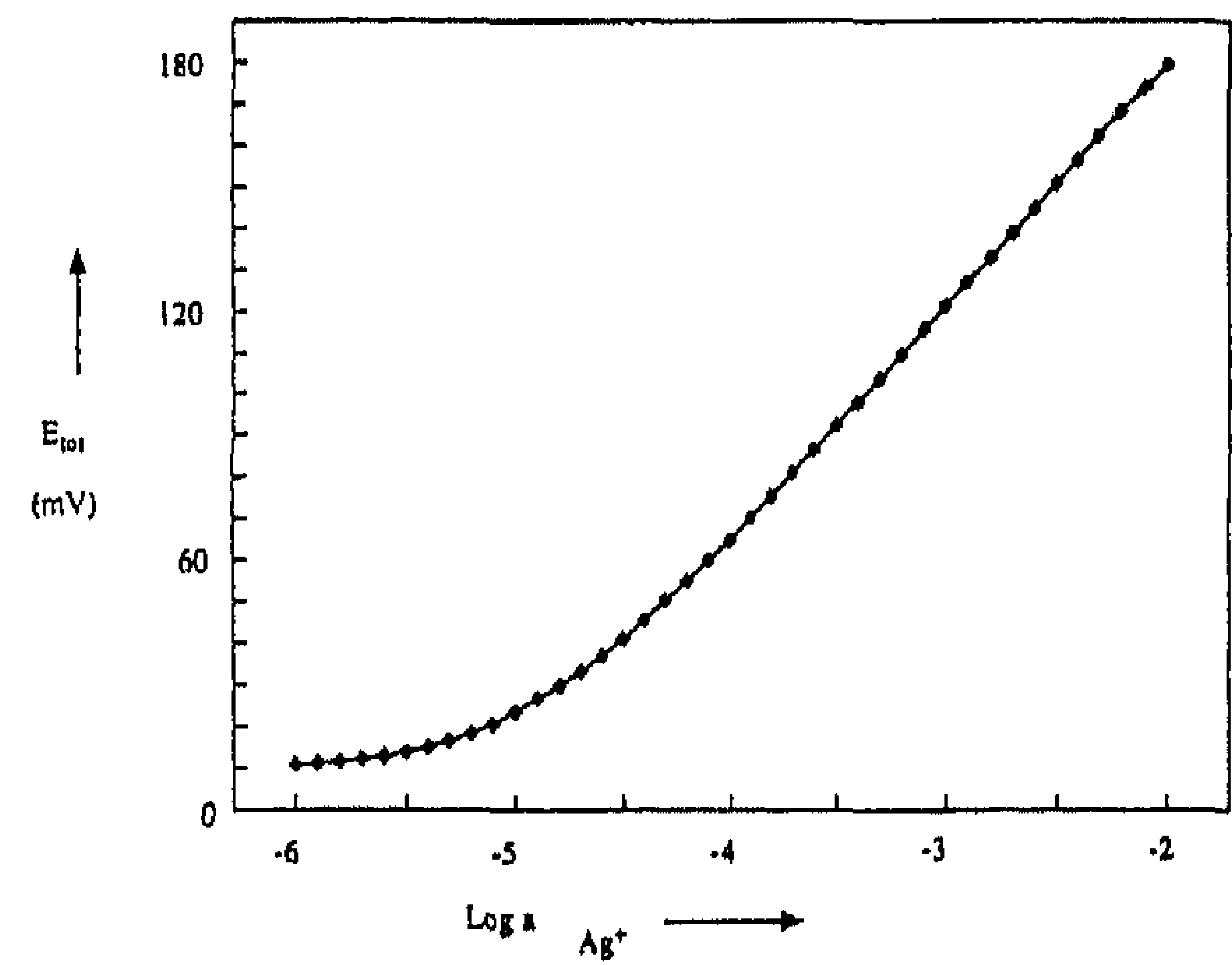

Figure 2. $\mathrm{Ag}^{+}$responses of CHEMFETs containing calix [4]arene ionophore 2 in the presence of $0.1 \mathrm{M} \mathrm{Ca}\left(\mathrm{NO}_{3}\right)_{2}$.

[4]arenes 2 and 5 are the highest $\left(\log K_{1, j}=-2.7\right)$ and comparable to the best ISE known so far. An increase of the number of sulfur atoms to four (compound 3 ) lowers the selectivity $\left(\log K_{l, j}=-2.3\right)$, The dehydroxylated receptor molecule 9 had the lowest selectivity $\left(\log K_{\mathrm{i},}=-2.1\right)$. Probably the increased flexibility in the calix[4]arene skeleton enables the two sulfur atoms to accommodate the smaller mercury ion better.

Copper and Cadmium Selectlve CHEMFETs. Copper. Two calix [4]arene based ionophores have been applied in a CHEM. FET, viz. 13 with four and 17 with two thiocarbamoyl groups, and evaluated for the selectivity toward copper(II) ions, ${ }^{32}$ The polyHEMA layer of these CHEMFETs was soaked in an aqueous

(33) 2,6-Dimethyl-1-[2-(methylthio)ethoxy]benzene is also selective to ward silver versus potassium, calcium, cadmium, and copper. However, the ward silver versus potassium, calcium, cadmium, and copper. However, the interference of mercury is severe (log $\mathcal{K}_{\mathrm{f}}=-0.2$ ), which stresses the beneficia design of the synthesized silver selective calix [4]arenes, 2,6-Dimethyl-1[2-(methylthio)ethoxy]benzene was prepared in $63 \%$ yield in analogy with the procedure given for the preparation of 2: ${ }^{1} \mathrm{H}$ NMR $87.0-6.85(\mathrm{~m}, 3 \mathrm{H}, \mathrm{ArH})$ $3.94\left(\mathrm{t}, 2 \mathrm{H}, J=6.8 \mathrm{~Hz}, \mathrm{ArOCH}_{2}\right), 2.89\left(\mathrm{t}, 2 \mathrm{H}, J=6.8 \mathrm{~Hz}, \mathrm{CH}_{2} \mathrm{~S}\right), 2.29$ $\left(s, 6 \mathrm{H}_{1} \mathrm{ArCH}_{3}\right), 2.20\left(\mathrm{~s}, 3 \mathrm{H}, \mathrm{SCH}_{3}\right)$ 


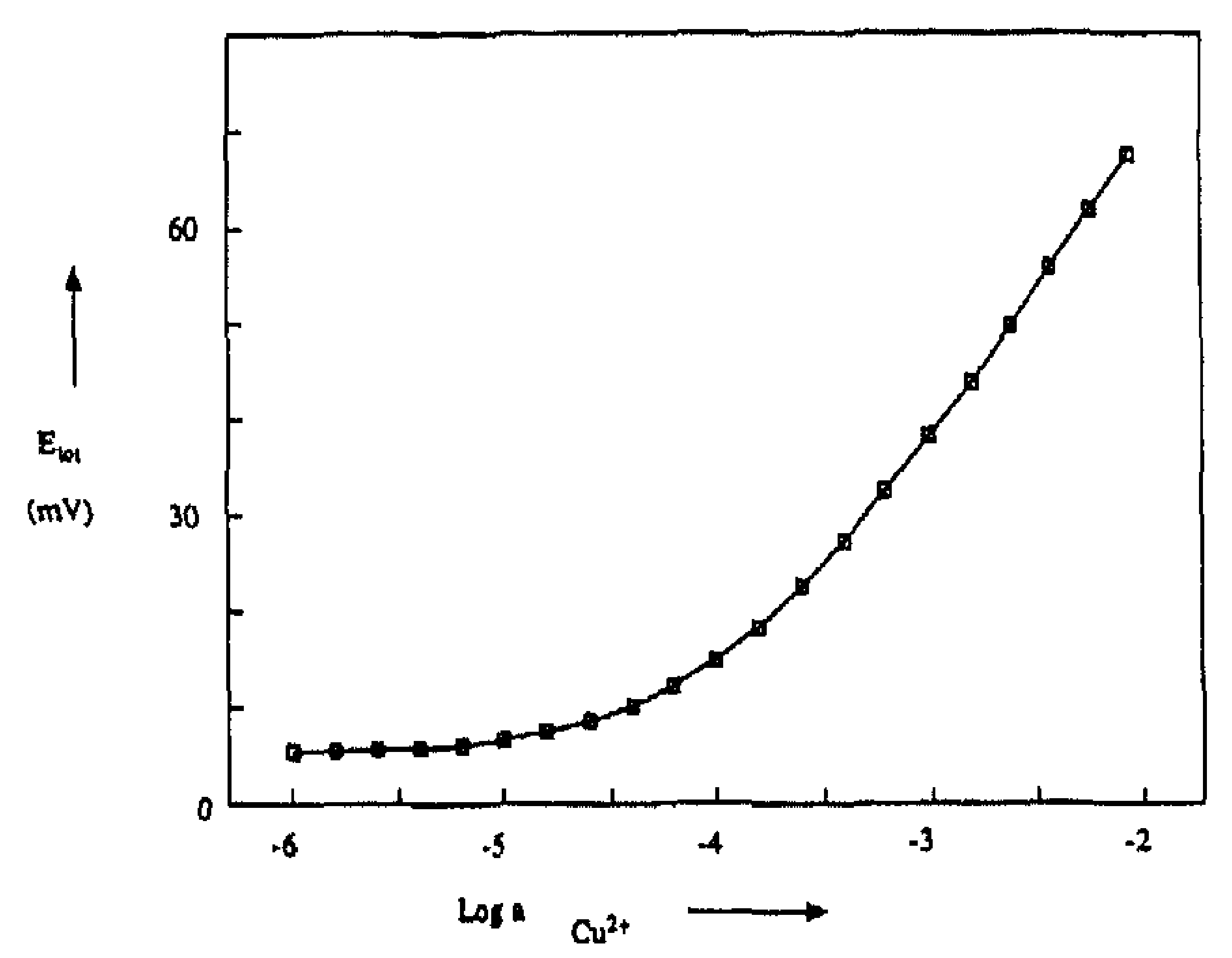

Figure 3. $\mathrm{Cu}^{2+}$ response of CHEMFETs containing ionophore 13 in the presence of $0.01 \mathrm{M} \mathrm{Ca}\left(\mathrm{NO}_{3}\right)_{2}$.

copper (0.01 M, HCl, $\mathrm{pH}=4)$ solution.

The calix[4]arene ionophore $13(2.6 \mathrm{wt} \%)$ with four thiocarbamoyl groups was incorporated in a PVC/DOP ( $=$ bis $(2$ ethylhexyl)phthalate) membrane containing potassium tetrakis(4-chlorophenyl)borate (1.4 wt\%). The CHEMFETs with such a membrane respond Nernstian ( $31 \mathrm{mV}$ decade $^{-1}$ ) to copper(II) ions (Figure 3 ).

CHEMFETs with a PVC/DOP membrane and only potassium tetrakis (4-chlorophenyl) borate, without ionophore 13, did not respond at all to copper(II) ions. The PVC/DOP system with ionophore 13 was selective for copper(II) ions in the presence of calcium $\left(\log K_{i, j}=-1.7\right)$, cadmium $\left(\log K_{i, j}=-2.0\right)$, and lead (log $K_{1}=-1.6$ ). Potassium chloride interferes with the electrode response (Table II, entry 1), which might be due to the higher partition of potassium to the membrane compared to copper(II) ions. A more polar membrane plasticizer (e.g., o-nitrophenyl octyl ether (o-NPOE)) can increase the selectivity toward copper versus potassium cations, but PVC/O-NPOE based CHEMFETs with the same ionophore responded not reproducible to copper(II) ions.

The calix [4] arene ionophore 17 with two thiocarbamoyl groups, incorporated in a PVC/DOP membrane containing potassium tetrakis (4-chlorophenyl)borate, responded irreproducibly to copper(II) ions. Better results were obtained in a PVC/O-NPOE membrane, although the amount of ionophore had to be raised to $9.2 \mathrm{wt} \%$ in order to obtain a stable sensor. These CHEMFETs responded selectively toward copper(II) ions with a slope of 54-59 $\mathrm{mV}$ decade ${ }^{-1}$ (Table II, entry 2). An increased slope of $60 \mathrm{mV}$ decade $e^{-1}$ for a divalent cation was described earlier by Lindner et al. ${ }^{34}$ using a lead-selective electrode. Lead is detected as the monovalent species of the type $\mathrm{PbX}+\left(\mathrm{X}=\mathrm{OH}^{-}, \mathrm{Cl}^{-}, \mathrm{CH}_{3} \mathrm{COO}^{-}\right)$. Thus, the slope of $60 \mathrm{mV}$ decade $e^{-1}$ is obtained. It might also be possible that sample anions associate in the sensing membrane with the cation-ionophore complex, which leads to an increased slope of this copper response. For copper in the presence of potassium chloride no selective response was found. The potentiometric selectivity coefficients of copper versus calcium, cadmium, and lead are $-1.9,-2.1$, and -1.7 , respectively. Membranes without ionophore 17 present showed no intrinsic selectivity toward copper(II) ions.

Cadmium. The thioamide functionality of the cadmium ionophore $N, N, N^{\prime}, N^{\prime}$ tetrabutyl-3,6-dioxaoctanedithioamide ${ }^{30}$ is also present in the four synthesized novel calix[4]arenes 19, 21, 23, and 25. These calix [4] arenes were used in DOP plasticized PVC membranes in a CHEMFET. The polyHEMA hydrogel of the CHEMFET was conditioned with $0.01 \mathrm{M} \mathrm{Cd}\left(\mathrm{NO}_{3}\right)_{2}\left(\mathrm{HNO}_{3}, \mathrm{pH}\right.$ - 4). The results of the measurements ${ }^{32}$ of the CHEMFETs are summarized in Table III.

(34) Lindner, E.; Toth, K.i Pungor, E.; Behm, F; Oggenfuss, P.; Welti, D. H.i Ammann, D.; Morf, W. E,; Pretsch, E.; Simon, W. Anal. Chem. 1984, S6, $1127-1131$.
Table III. Selectivity Data of $\mathrm{Cd}^{2+}$ Selective CHEMFETs Containing Different Calix [4] arene Ionophores $(19,21,23$, or 25) in the Presence of Different Interfering Nitrate Salts

\begin{tabular}{|c|c|c|c|c|c|c|}
\hline \multirow[b]{2}{*}{ entry } & \multirow[b]{2}{*}{$\begin{array}{c}\text { ionophore } \\
\text { (wt\%) }\end{array}$} & \multirow[b]{2}{*}{$\begin{array}{c}\text { KTCPB } \\
(w t \%)\end{array}$} & \multicolumn{4}{|c|}{ interfering ions } \\
\hline & & & $\begin{array}{c}\overline{\mathrm{Ca}\left(\mathrm{NO}_{3}\right)_{2}} \\
(0.1 \mathrm{M})\end{array}$ & $\begin{array}{c}\mathrm{KNO}_{3} \\
(0.1 \mathrm{M})\end{array}$ & $\begin{array}{c}\mathrm{Cu}\left(\mathrm{NO}_{3}\right)_{2} \\
(0.01 \mathrm{M})\end{array}$ & $\begin{array}{c}\mathrm{Pb}\left(\mathrm{NO}_{3}\right)_{2} \\
(0.01 \mathrm{M})\end{array}$ \\
\hline 1 & $19(2.1)$ & $(1.7)$ & $\begin{array}{l}-3.2 \\
(30 \mathrm{mV})\end{array}$ & $a$ & $\begin{array}{l}-0.6 \\
(22 \mathrm{mV})\end{array}$ & $a$ \\
\hline 2 & $21(2.3)$ & $(1.7)$ & $\begin{array}{l}-2.3 \\
(25 \mathrm{mV})\end{array}$ & $a$ & $a$ & $a$ \\
\hline 3 & $23(2.8)$ & $(0.8)$ & $\begin{array}{l}-3.9 \\
(30 \mathrm{mV})\end{array}$ & $\begin{array}{l}-2.5 \\
(29 \mathrm{mV})\end{array}$ & a & a \\
\hline 4 & $23(3)$ & (2) & $\begin{array}{l}-3.8 \\
(30 \mathrm{mV})\end{array}$ & $\begin{array}{l}-2.6 \\
(29 \mathrm{mV})\end{array}$ & $a$ & $a$ \\
\hline 5 & $25(2.1)$ & $(0,8)$ & $\begin{array}{l}-3.2 \\
(29 \mathrm{mV})\end{array}$ & $a$ & $a$ & $a$ \\
\hline
\end{tabular}

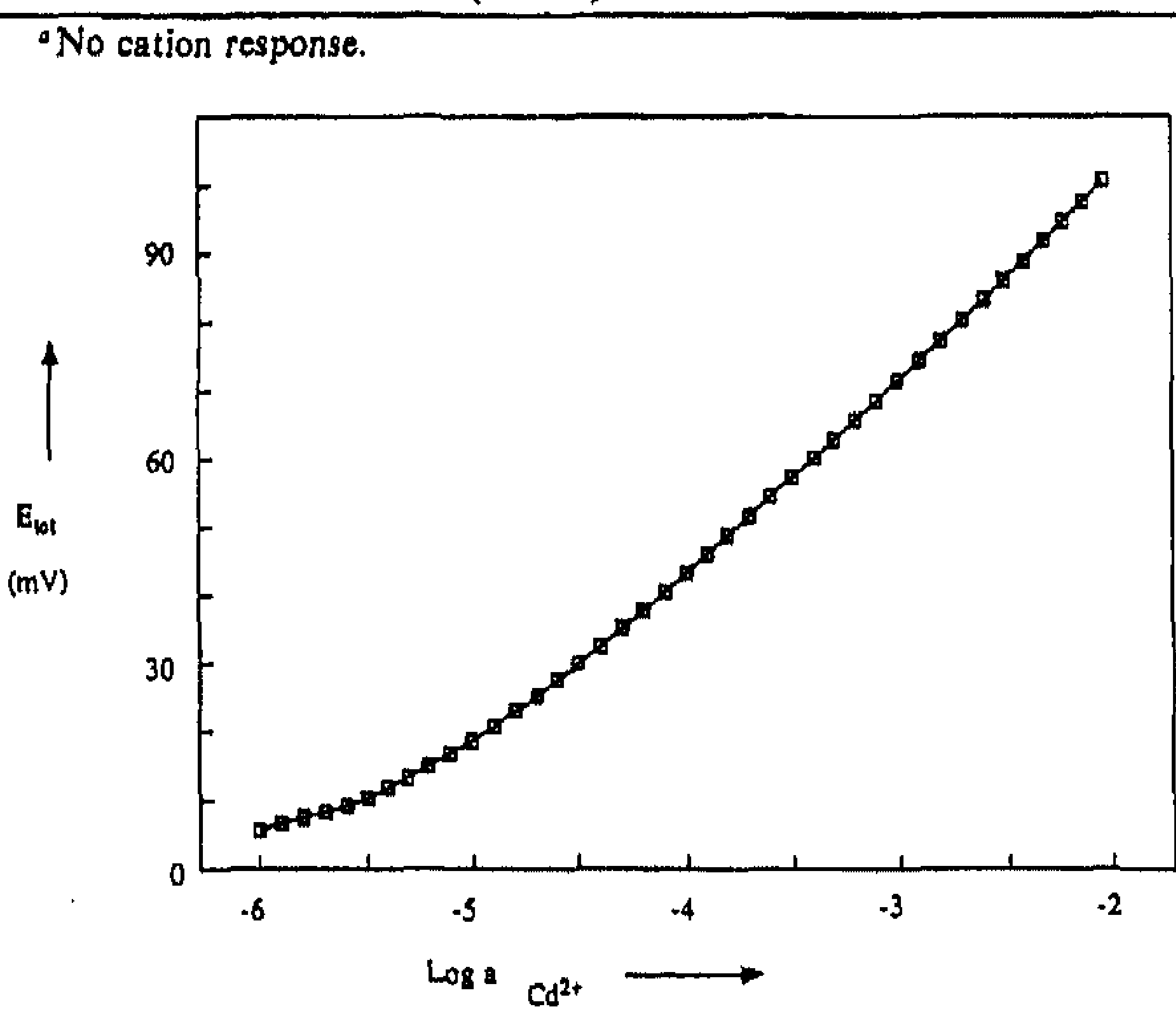

Figure 4. $\mathrm{Cd}^{2+}$ response of CHEMFETs containing calix[4]arene ionophore 23 in the presence of $0.1 \mathrm{M} \mathrm{Ca}\left(\mathrm{NO}_{3}\right)_{2}$.

The 26,28-difunctionalized calix[4]arene 19 exhibits a Nernstian response $\left(22-30 \mathrm{mV}\right.$ decade $\left.{ }^{-1}\right)$ toward cadmium in the presence of calcium ( $\left.\log K_{\mathrm{ij}}=-3.2\right)$ and of copper(II) ions (log $K_{1 j}=-0,6$, Table III, entry 1). Variation of the disubstitution pattern from 26,28 (compound 19) to 27,28 (compound 21) revealed that the 26,28 -disubstituted 19 is more selective than the 27,28-disubstituted 21. The 27,28-difunctionalized calix[4]arene 21 showed, compared to compound 19, a decreased selectivity for cadmium(II) ions versus calcium ( $\left.\log K_{i j}=-2.3\right)$ and copper(II) $\left(\log K_{i j}>0\right)$ (Table III, entries 1 and 2 ).

Two calix [4]arene based ionophores (23 and 25) with an $\mathrm{ex}$ tended cavity, were synthesized in order to study the effect of the flexibility of the coordinating groups which are attached to the calix[4]arene building block. The tetraalkylated 23 shows the best results. Incorporated in the membrane of the CHEMFET, this ionophore introduces selectivity for cadmium ions (Figure 4) over calcium $\left(\log K_{1 j}=-3.9\right)$ and potassium $\left(\log K_{i j}=-2.6\right)$ ions (Table III, entry 1), A CHEMFET with compound 23 exhibits no selectivity for cadmium in the presence of lead(II) ions or copper(II) ions. The introduction of a larger amount of potassium tetrakis(4-chlorophenyl) borate (Table III, entry 4) did not change the selectivity coefficients.

The tetraalkylation proved to be necessary because the 26,28-disubstituted 25 showed no selectivity versus potassium, while the selectivity coefficient versus calcium decreased to log $K_{1}=-3.2$.

Lead Selective CHEMFETs, CHEMFETs Based on Oxamide Ionophores. Several dioxamides have been reported by Lindner et al. ${ }^{34}$ to induce selectivity toward lead(II) ions in an ion-selective electrode.

The novel calix [4]arene ionophores 24 and 26 were also incorporated in these PVC/BBPA ( = bis(butylpentyl)adipate) based CHEMFETs, ${ }^{32}$ The polyHEMA hydrogel was conditioned in a lead(II) chloride solution $\left(0.01 \mathrm{M}, 10^{-3} \mathrm{M} \mathrm{Mg}(\mathrm{OAc})_{2} / \mathrm{HCl} \mathrm{pH}\right.$ 
Table IV, Selectivity Data of $\mathrm{Pb}^{2+}$ Selective CHEMFETs Containing Different Ionophores (24 or 26) in the Presence of Different Interfering Chloride Salts ${ }^{\text {A }}$

\begin{tabular}{cccccccc}
\hline & & & \multicolumn{4}{c}{ interfering ions } \\
\cline { 5 - 7 } entry & $\begin{array}{c}\text { ionophore } \\
(w 1 \%)\end{array}$ & $\begin{array}{c}\text { KTCPB } \\
(w t \%)\end{array}$ & $\begin{array}{c}\mathrm{KCl} \\
(0.01 \mathrm{M})\end{array}$ & $\begin{array}{c}\mathrm{CaCl}_{2} \\
(0.01 \mathrm{M})\end{array}$ & $\begin{array}{c}\mathrm{CdCl} \\
(0.01 \mathrm{M})\end{array}$ & $\begin{array}{c}\mathrm{CvCl}_{2} \\
(0.01 \mathrm{M})\end{array}$ \\
\hline 1 & $26(2)$ & $(0.8)$ & $c$ & -3.2 & -3.3 & $-3.0^{d}$ \\
2 & $24(2.1)$ & $(0.8)$ & $c$ & -2.4 & -2.7 & -2.3 \\
& & & & $(26 \mathrm{mV})$ & $(30 \mathrm{mV})$ & $(30 \mathrm{mV})$ \\
3 & none $^{b}$ & $(0.8)$ & $c$ & -1.2 & -1.4 & $c$ \\
& & & & $(<15 \mathrm{mV})$ & $(24 \mathrm{mV})$ & \\
\hline
\end{tabular}

- PVC:BBPA $\approx 1: 2$. ${ }^{b}$ Not present. "No cation response. ${ }^{d}$ Corrected for drift.

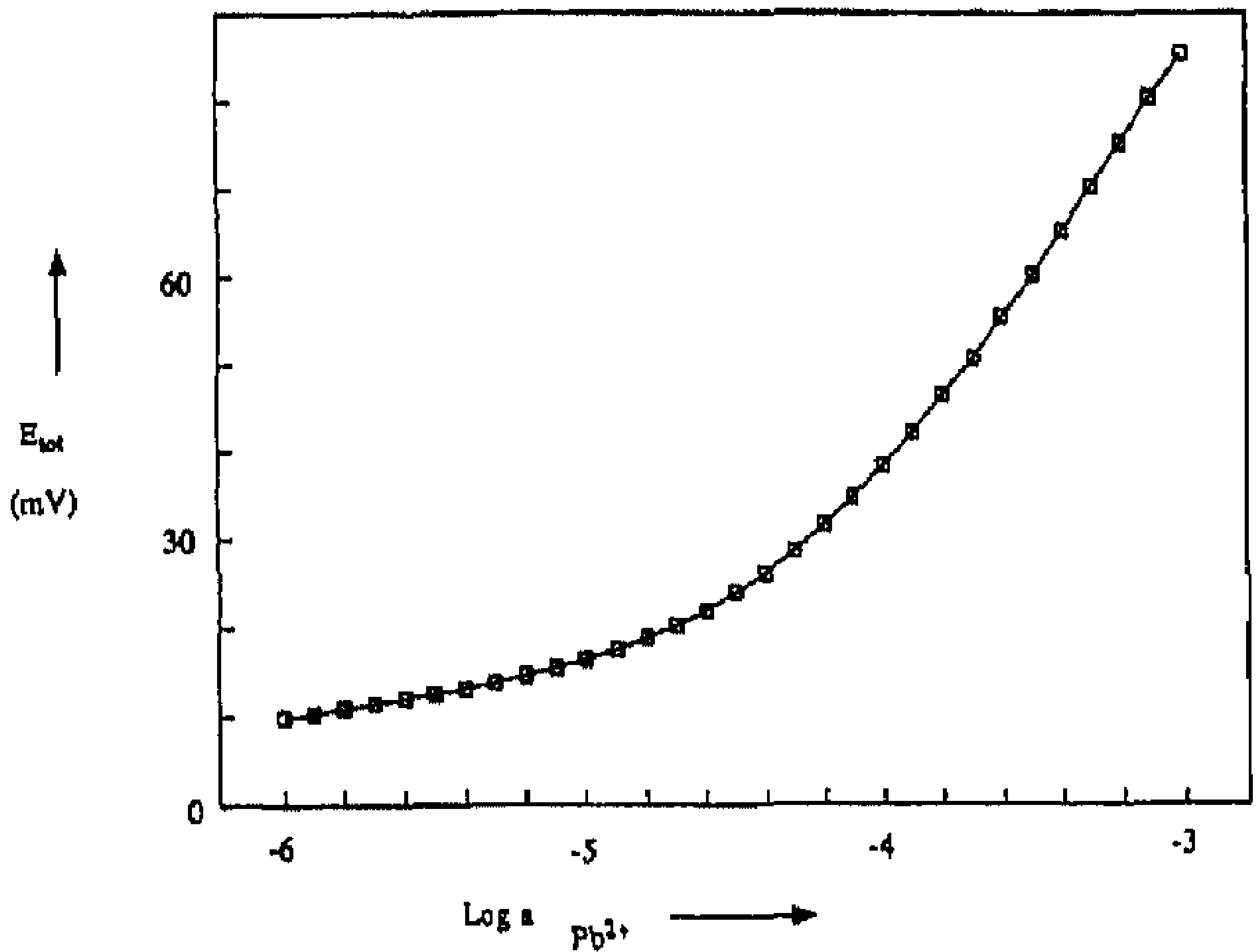

Figure 5. $\mathrm{Pb}^{2+}$ response of CHEMFETs containing calix[4]arene ionophore 26 in the presence of $0.01 \mathrm{M} \mathrm{Cd}\left(\mathrm{NO}_{3}\right)_{2}$

-4). Addition of potassium tetrakis(4-chlorophenyl)borate appeared to be necessary in order to obtain reproducible and stable electrical signals. Without ionophore (Table IV, entry 3) only a slight selectivity toward calcium and cadmium ions was observed. Both calix[4]arene ionophores 24 and 26 are selective for lead(II) ions with respect to calcium, cadmium, and copper. Potassium interfered in both CHEMFETs. Calix[4]arene 26 gave a slope of around $50 \mathrm{mV}$ per decade ${ }^{35}$ (Figure 5 ) as observed for otber oxamide ionophores by Lindner et al. ${ }^{34}$

The other CHEMFETs based on calix [4] arene 24 showed a response of $30 \mathrm{mV}$ per decade, as expected for a divalent cation. This difference in slope, nearly $60 \mathrm{mV}$ of calix[4]arene 26 and $30 \mathrm{mV}$ of calix [4]arene 24 , implies a difference in complexation properties. It is possible that calix [4]arene 26 complexes a monovalent $\mathrm{PbX}^{+}$species, because the rigidity of the calix [4]arene block hinders complete surrounding of the divalent lead cation by donor atoms. The more flexible functional groups of calix[4] arene 24 are able to complex the divalent lead cation completely.

The selectivities of CHEMFETs based on ionophore 26 are in the order of $-3.0-3.2\left(\log K_{1 j}\right.$, Table IV, entry 1). The selectivities of the CHEMFETs in which calix[4]arene 24 was incorporated were between $\left(\log K_{\mathrm{ij}}\right)-2.3$ and -2.7 (Table IV, entry 2)

CHEMFETs Based on Thloamide Ionophores. In membranes of lon-selective electrodes or CHEMFETs oxamides are used as receptor molecules. ${ }^{34,36}$ However, a thioamide functionalized calix [4]arene was reported which extracted in a high percentage lead(II) cations from an aqueous to a dichloromethane layer. ${ }^{37}$

(35) Battllotti et al. 36" have found a selective response of a CHEMFET oward $\mathrm{PbX}^{+}$species $\left(\mathrm{X}-\mathrm{Cl}^{-}\right.$or $\left.\mathrm{OH}^{-}\right)$of $60 \mathrm{mV}$ decade- with the ligand $N, N, N_{1}^{\prime} N^{\prime}$-tetrabutyl-3,6-dioxaoctanediamide. The selectivity coefficients cannot be compared because of the different experimental conditions.

(36) (a) Battilotli, M.; Mercuri, R.; Mazzamurro, G.; Gianninl, L.; Giongo, M. Sens. Actuators 1990, B1, 438-440. (b) Malinowska, E. Analyst 1990, $115,1085-1087$

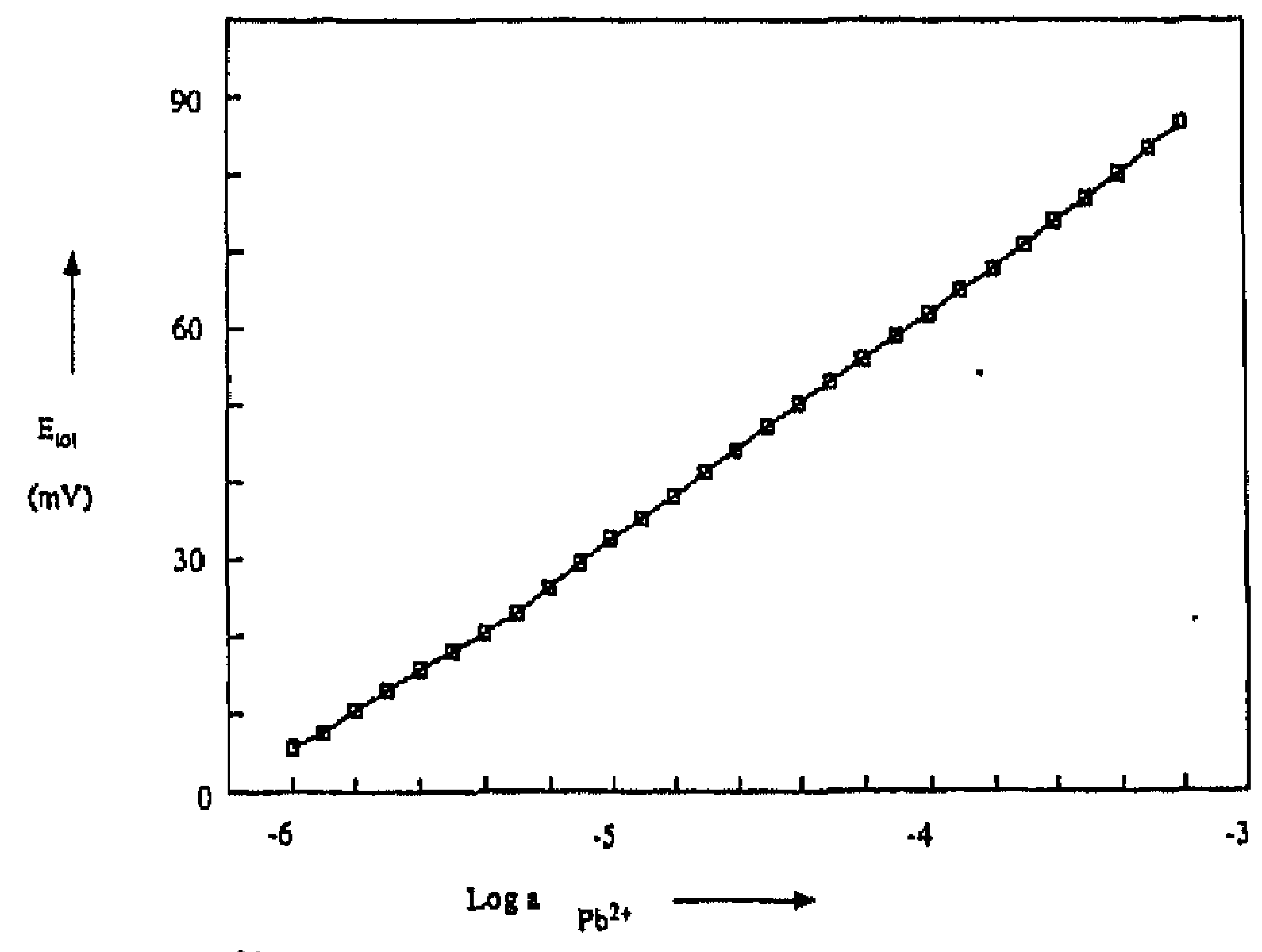

Figure 6. $\mathrm{Pb}^{2+}$ response of CHEMFETs containing calix[4]arene tonophore 29 in the presence of $1 \mathrm{M} \mathrm{KCl}$.

Table V. Selectivity Data of $\mathrm{Pb}^{2+}$ Selective CHEMFETs Containing Different Calix [4]arene Ionophores $(19,27$ or 29) in the Presence of Different Interfering Chloride Salts ${ }^{a}$

\begin{tabular}{ccccccc}
\hline & & \multicolumn{4}{c}{ interfering ions } \\
\cline { 4 - 7 } entry & $\begin{array}{c}\text { ionophore } \\
(w \mathrm{t} \%)\end{array}$ & $\begin{array}{c}\mathrm{KTCPB} \\
(\mathrm{wt} \%)\end{array}$ & $\begin{array}{c}\mathrm{KCl} \\
(0.1 \mathrm{M})\end{array}$ & $\begin{array}{c}\mathrm{CaCl}_{2} \\
(0.1 \mathrm{M})\end{array}$ & $\begin{array}{c}\mathrm{CdCl}_{2} \\
(0.01 \mathrm{M})\end{array}$ & $\begin{array}{c}\mathrm{CuCl}_{2} \\
(0.01 \mathrm{M})\end{array}$ \\
\hline 1 & $29(2)$ & $(0.8)$ & $-5.2^{b}$ & -4.3 & $-4.2^{c}$ & $-3.4^{6}$ \\
& & & $(32 \mathrm{mV})$ & $(30 \mathrm{mV})$ & $(30 \mathrm{mV})$ & $(31 \mathrm{mV})$ \\
2 & $19(2)$ & $(0.7)$ & -2.4 & -3.7 & -1.9 & -1.7 \\
& & & $(27 \mathrm{mV})$ & $(31 \mathrm{mV})$ & $(31 \mathrm{mV})$ & $(22 \mathrm{mV})$ \\
3 & $27(2)$ & $(0.9)$ & -2.8 & -4.2 & -1.7 & -2.7 \\
& & & $(32 \mathrm{mV})$ & $(29 \mathrm{mV})$ & $(22 \mathrm{mV})$ & $(29 \mathrm{mV})$ \\
\hline
\end{tabular}

"PVC:O-NPOE $\approx 1: 2,1 \mathrm{M} \mathrm{KCl},{ }^{\circ} 0.1 \mathrm{M}$.

Therefore, several thioamide containing calix[4]arenes $(19,27$, and 29) were synthesized.

All the calix[4] arenes were incorporated in PVC/O-NPOE membranes containing potassium tetrakis(4-chlorophenyl)borate. Without any ionophore no selectivity toward lead(II) ions was observed. The receptor molecule 29 introduced in the CHEMFET showed (Figure 6) a high selectivity toward lead with a Nernstian slope of $30 \mathrm{mV}$ decade ${ }^{-1}$ (Table $V$, entry 1). Copper interfered most $\left(\log K_{i \mathrm{j}}=-3,4\right)$. The interference of calcium and cadmium was less ( $\log K_{\mathrm{i}, \mathrm{j}}=$ ca. -4.2 ), and potassium showed hardly any interference $\left(\log K_{i j}=-5.2\right)$,

When the number of thioamide groups are reduced from four to two this lowers the selectivity toward lead cations (Table V, entries 2 and 3 ). If calcium was the interfering ion the deviation from compound 29 was the smallest $(-0.6$ (compound 19) or -0.1 (compound 27)). But toward the other interfering ions (potassium, cadmium, and copper) this difference is more pronounced (compare in Table $V$ entries 2 and 3 to entry 1). This leads to the conclusion that four thioamide groups are a prerequisite in a calix [4]arene based ionophore for the selective complexation of lead(II) ions.

\section{Conclusions}

In this paper the first sensors for heavy metal ions based on ion-sensitive field effect transistors (ISFETs) are described, Several new calix [4]arenes are designed and synthesized for the selective recognition of silver, copper, cadmium, and lead cations.

(37) Perrin, R.; Harris, S. Industrial Applications of Callxarenes in ref

(38) Gutsche, C. D.i Iqbal, M.; Stewart, D. J, Org. Chem. 1986, 5I, $742-745$

(39) Gutsche, C. D.; Lin, L.-G. Tetrahedron 1986, 42, 1633-1640.

(40) Bergueld, P. Sens. dciuators 1981, /, 17-29

(41) Sudhölter, E. J. R.; van der Wal, P. D.; Skowronska-Ptasinska, M.; van den Berg, A.; Reinhoudt, D. N. Sens. Actwators 1989, 17, 189-194. 


\section{Experimental Section}

Synthesls, General Methods. 'H and ${ }^{13} \mathrm{C}$ NMR spectra were recorded with a Bruker $\mathrm{AC} 250 \mathrm{~F}\left(250 \mathrm{MHz}\right.$ ) spectrometer in $\mathrm{CDCl}_{3}$ unless stated otherwise with TMS as an internal standard. FAB mass spectra were obtained with a Finnigan MAT90 mass spectrometer using $m$-nitrobenzyl alcohol (NBA) or polyethyleneglycol (PEG) as a matrix, Melting points were determined with a Reichert melting point apparatus and are un. corrected. Tetrahydrofuran was freshly distilled from sodium/benzophenone kety); acetonitrile was dried over molecular sieves ( $3 A$ ); DMF was stored over molecular sieves $(4 \AA)$; pyridine was dried over $\mathrm{KOH}$ pellets prior to use. Petroleum ether refers to the fraction boiling at $60-80^{\circ} \mathrm{C}$, unless stated otherwise. All other solvents and chemicals were of reagent grade and were used without purification. Chromatographic separations were performed on silica gel $60\left(\mathrm{SiO}_{2}\right.$, E. Merck, particle size $0.040-0.063 \mathrm{~mm}, 230-240$ mesh), whereas preparative TLC was performed on $\mathrm{SiO}_{2}$ preparative plates (E. Merck, thickness $2.0 \mathrm{~mm}$ ). Compounds $1,{ }^{38^{2}} 4,{ }^{23} 6^{39} 10,{ }^{27}$ and $28^{31}$ were prepared according to the literature. All reactions were carried out under an argon atmosphere. The presence of solvent in the samples for elemental analysis was confirmed by 'H NMR spectroscopy. For reasons of clarity and in order to reduce space, the name callx 4 ] arene was used instead of the original IUPAC name: pentacyclo[19,3.1.13,7, $\left.1^{9,13}, 1^{15,19}\right]$ octacosa-1(25),3,5,7. (28),9,11,13(27),15,17,19(26),21,23-dodecaene.

5,11,17,23-Tetrakis (1,1-dimethylethyl)-25,27-dlhydroxy-26,28-bis;2(methylthio)ethoxy]callix[4]arene (2). A mixture of p-tert-butylcalix[4]arene $1(19.20 \mathrm{~g}, 29,6 \mathrm{mmol})$, 2-chloroethyl methy] sulfide $(9.81 \mathrm{~g}$ $88.7 \mathrm{mmol})$, and $\mathrm{K}_{2} \mathrm{CO}_{3}(4.09 \mathrm{~g}, 29.6 \mathrm{mmol})$ in acetonitrile $(500 \mathrm{~mL})$ was refluxed for $20 \mathrm{~h}$. After cooling to room temperature, the solvent was evaporated under reduced pressure. $\mathrm{HCl}(2 \mathrm{~N}, 200 \mathrm{~mL})$ was added, and the slurry was extracted with $\mathrm{CH}_{2} \mathrm{Cl}_{2}(2 \times 200 \mathrm{~mL})$. The combined organic layer was washed with brine $(300 \mathrm{~mL})$, dried over $\mathrm{MgSO}_{4}$ and evaporated under reduced pressure. The resulting oil was crystallized with $\mathrm{MeOH}$ to afford 2 as a white powder $(15.92 \mathrm{~g}, 67 \%)$, which was pure enough for further reactions. An analytical sample was recrystallized from $\mathrm{CH}_{2} \mathrm{Cl}_{2} / \mathrm{MeOH}$ : mp 220-222 ${ }^{\circ} \mathrm{C}^{\prime}{ }^{\prime} \mathrm{H}$ NMR $87.06,6.76$ (s, $4 \mathrm{H}, \mathrm{ArH}), 4.31$ and $3.32\left(\mathrm{ABq}, 8 \mathrm{H}, J=13.1 \mathrm{~Hz}, \mathrm{ArCH}_{2} \mathrm{Ar}\right), 4.13$ ( $\mathrm{t}$, $\left.4 \mathrm{H}_{1} J=7.0 \mathrm{~Hz}_{1} \mathrm{ArOCH}_{2}\right), 3.06\left(\mathrm{t}, 4 \mathrm{H}, J=6.9 \mathrm{~Hz}, \mathrm{OCH}_{2} \mathrm{CH}_{2}\right), 2.29$ $\left(\mathrm{s}, 6 \mathrm{H}, \mathrm{SCH}_{3}\right) ;{ }^{13} \mathrm{C}$ NMR $\delta 150.3,149.5$ (s, Ar 25,26,27,28.C), 146.7 , 141.3 (s, Ar 5,11,17,23-C), 132,6, 127,6 (s, Ar 1,3,7,9,13,15,19,21-C) 125.3, $124.9(\mathrm{~d}$, all $\mathrm{ArC}-\mathrm{H}), 75.2(\mathrm{t}, \mathrm{ArOCH})_{2}, 33.7,33.6\left[\mathrm{~s}, \mathrm{C}\left(\mathrm{CH}_{3}\right)_{3}\right]$ $33.3\left(\mathrm{t}, \mathrm{OCH}_{2} \mathrm{CH}_{2}\right), 31.5,30.8\left[\mathrm{q}, \mathrm{C}\left(\mathrm{CH}_{3}\right)_{3}\right], 31.4\left(\mathrm{t}, \mathrm{ArCH}_{2} \mathrm{Ar}\right), 16.2$ $\left(\mathrm{q}, \mathrm{SCH}_{3}\right) ; \mathrm{FAB}$ mass spectrum $(\mathrm{NBA}), \mathrm{m} / \mathrm{e} 797.4\left[(\mathrm{M}+\mathrm{H})^{+}\right.$, calcd 797.5]. Anal. Caled for $\mathrm{C}_{50} \mathrm{H}_{68} \mathrm{O}_{4} \mathrm{~S}_{2} \cdot 0.1 \mathrm{CH}_{2} \mathrm{Cl}_{2} ; \mathrm{C}, 74.69 ; \mathrm{H}, 8.46$. Found: $\mathrm{C}, 74.57 ; \mathrm{H}, 8.56$

$5,11,17,23-T e t r a k i s(1,1$-dimethylethyl) - 25,26,27,28-tetrakis[ (2methylthio)ethoxy)callx[4]arene (3). A suspension of dihydroxybis[(methylthio)ethoxy]-p-tert-butylcalixarene $2(7.60 \mathrm{~g}, 8.72 \mathrm{mmol})$ and $\mathrm{NaH}$ [1.31 g, $43.6 \mathrm{mmol}$; freed from mineral oil by washing with petroleum ether $\left.\left(\mathrm{bp} 40-60^{\circ} \mathrm{C}\right)(2 \times 5 \mathrm{~mL})\right]$ in DMF $(150 \mathrm{~mL})$ was stirred at room temperature for $1 \mathrm{~h}$. Subsequently, 2-chloroethyl methyl sulfide $(6.75 \mathrm{~g}, 61.0 \mathrm{mmol})$ was added, and the mixture was stirred at $55^{\circ} \mathrm{C}$ for $20 \mathrm{~h}$. The solvent was removed under reduced pressure, and $\mathrm{CH}, \mathrm{Cl},(300$ $\mathrm{mL}$ ) was added to the residue. The mixture was extracted with $2 \mathrm{~N} \mathrm{HCl}$ $(200 \mathrm{~mL})$, and washed with saturated $\mathrm{NH}, \mathrm{Cl}(4 \times 200 \mathrm{~mL})$ to remove traces of DMF. After drying of the organic layer with $\mathrm{MgSO}_{4}$, the solvent was removed under reduced pressure. 'H NMR spectroscopy showed that the conversion had not been complete, and therefore the crude mixture was treated once more with the same quantity of base and alkylating agent. After workup the crude product was purified by column chromatography $\left[\mathrm{SiO}_{2}, \mathrm{CH}_{2} \mathrm{Cl}_{2} /\right.$ petroleum ether (bp $40-60^{\circ} \mathrm{C}$ ) 1:1] to yield 3 as a white powder $(5.03 \mathrm{~g}, 61 \%)$ : mp $207-210^{\circ} \mathrm{C}\left(\mathrm{CH}_{2} \mathrm{Cl}_{2}\right)$ MeOH): 'H NMR $\delta 6.79(\mathrm{~s}, 8 \mathrm{H}, \mathrm{ArH}), 4.38$ and $3.15(\mathrm{ABq}, 8 \mathrm{H}, J=$ $\left.12.7 \mathrm{~Hz}, \mathrm{ArCH}_{2} \mathrm{Ar}\right), 4.06\left(\mathrm{t}, 8 \mathrm{H}, J=7.8 \mathrm{~Hz}, \mathrm{ArOCH}_{2}\right), 3.09(\mathrm{t}, 8 \mathrm{H}$, $\left.J=7.8 \mathrm{~Hz}, \mathrm{ArOCH}_{2} \mathrm{CH}_{2}\right), 2.21\left(\mathrm{~s}, 12 \mathrm{H}, \mathrm{SCH}_{3}\right), 1.07[\mathrm{~s}, 36 \mathrm{H}, \mathrm{C}-$ $\left.\left(\mathrm{CH}_{3}\right)_{3}\right] ;{ }^{13} \mathrm{C}$ NMR $\delta 152.8$ (s, Ar 25,26,27,28-C), 144.9 (s, Ar $5,11,17,23-C), 133.6(s$, Ar $1,3,7,9,13,15,19,21-C), 125.1$ (d, all ArC-H) $73.5\left(t, \mathrm{ArOCH}_{2}\right), 33.9\left[\mathrm{~s}, \mathrm{C}\left(\mathrm{CH}_{3}\right)_{3}\right], 33.4\left(\mathrm{t}_{1} \mathrm{CH}_{2} \mathrm{~S}\right), 31.4\left[\mathrm{q}, \mathrm{C}\left(\mathrm{CH}_{3}\right)_{3}\right]$, $31.1\left(\mathrm{t}_{\mathrm{ArCH}} \mathrm{Ar}\right), 15.8\left(\mathrm{~g}, \mathrm{SCH}_{3}\right)$; FAB mass spectrum (PEG), m/e 945.2[( $\mathrm{M}+\mathrm{H})^{+}$, calcd 945.5]. Anal. Calcd for $\mathrm{C}_{56} \mathrm{H}_{80} \mathrm{O}_{4} \mathrm{~S}_{4} ; \mathrm{C}_{1} 71.14 ;$ $\mathrm{H}, 8.53 ; \mathrm{S}, 13.56$. Found: $\mathrm{C}, 71,13 ; \mathrm{H}, 8.47 ; \mathrm{S}, 13.26$

3,11,17,23-Tetrakls(1,1-dimethylethyl)-25,27-bis(2-(metbylthlo)ethoxy]-26,28-dipropoxycalix [4]arene (5). A suspension of 25,27-dihydroxy-26,28-dipropoxy-p-tert-butylcalix [4] arene $4(1.05 \mathrm{~g}, 1.43 \mathrm{mmol})$ and $\mathrm{NaH}[0.43 \mathrm{~B}, 14.3$ mmol; freed from mineral oil by washing with petroleum ether (bp $\left.\left.40-60^{\circ} \mathrm{C}\right)(2 \times 5 \mathrm{~mL})\right]$ in DMF $(20 \mathrm{~mL})$ was stirred at room temperature for I h. Subsequently, 2-chloroethyl methyl sulfide $(2.38 \mathrm{~g}, 21.5 \mathrm{mmol})$ was added, and the mixture was stirred

(42) Meier, P, C, Anal. Chim. Acta 1982, 136, 363-368. overnight at $55-60^{\circ} \mathrm{C}$. The solvent was evaporated, and the residue was taken up in $\mathrm{CH}_{2} \mathrm{Cl}_{2}(150 \mathrm{~mL})$. After washing with saturated $\mathrm{NH}_{4} \mathrm{Cl}$ solution $(4 \times 100 \mathrm{~mL})$ and brine $(100 \mathrm{~mL})$, the organic phase was dried with $\mathrm{MgSO}_{4}$ and subsequently the solvent was removed under reduced pressure. 'H NMR spectroscopy showed that the alkylation had not been complete, and the crude material was treated once more under the same conditions with the same amounts of base and alkylating agent. After workup the product was crystallized from $\mathrm{MeOH}$ and purified by column chromatography $\left[\mathrm{SiO}_{2}, \mathrm{CH}_{2} \mathrm{Cl}_{2}\right.$ /petroleum ether (bp 40-60 ${ }^{\circ} \mathrm{C}$ ) $1: 2$ ] to give 5 as a white powder $(0.77 \mathrm{~g}, 61 \%): \mathrm{mp} 101-103^{\circ} \mathrm{C}(\mathrm{MeOH}) ;^{\prime} \mathrm{H}$ NMR $\delta 7.07(\mathrm{~s}, 4 \mathrm{H}, \mathrm{ArH}), 6.50(\mathrm{~s}, 4 \mathrm{H}, \mathrm{ArH}), 4.37$ and $3.14(\mathrm{ABg}$, $\left.8 \mathrm{H}, J=12.8 \mathrm{~Hz}, \mathrm{ArCH}_{2} \mathrm{Ar}\right), 4.17\left(\mathrm{t}, 4 \mathrm{H}, J=8.5 \mathrm{~Hz} \mathrm{OCH}_{2} \mathrm{CH}_{2} \mathrm{~S}\right)$ $3.69\left(\mathrm{t}, 4 \mathrm{H}, J=7.4 \mathrm{~Hz}, \mathrm{OCH}_{2} \mathrm{CH}_{2} \mathrm{CH}_{3}\right), 3.20\left(\mathrm{t}, 4 \mathrm{H}, J=8.5 \mathrm{~Hz}_{1}\right.$ $\left.\mathrm{OCH}_{2} \mathrm{CH}_{2} \mathrm{~S}\right), 2.21\left(\mathrm{~s}, 6 \mathrm{H}, \mathrm{SCH}_{3}\right), 2.0-1.85\left(\mathrm{~m}, 4 \mathrm{H}, \mathrm{OCH}_{2} \mathrm{CH}_{2} \mathrm{CH}_{3}\right)$, $1.05\left(\mathrm{t}, 6 \mathrm{H}, J=7.4 \mathrm{~Hz}, \mathrm{OCH}_{2} \mathrm{CH}_{2} \mathrm{CH}_{3}\right), 1.30,0.86\left[\mathrm{~s}, 18 \mathrm{H}, \mathrm{C}\left(\mathrm{CH}_{3}\right)_{3}\right] ;$ ${ }^{13} \mathrm{C}$ NMR $\delta 153.8,152.5$ (s, Ar 25,26,27,28-C), 145.1, 144.1 (s, Ar $5,11,17,23 \cdot \mathrm{C}), 135.3,132.1$ (s, Ar $1,3,7,9,13,15,19,21-\mathrm{C}), 125,5,124.6$ (d, all ArC-H), 77.6 (t, OCH $\left.\mathrm{CH}_{2} \mathrm{CH}_{3}\right), 73.3\left(\mathrm{t}, \mathrm{OCH}_{2} \mathrm{CH}_{2} \mathrm{~S}\right), 34.1,33.6$ $\left.\left[\mathrm{s}, \mathrm{C}\left(\mathrm{CH}_{3}\right)_{3}\right], 32.7\left(\mathrm{t}, \mathrm{OCH}_{2} \mathrm{CH}_{2} \mathrm{~S}\right), 31.7,31.2\left[\mathrm{q}, \mathrm{C}\left(\mathrm{CH}_{3}\right)_{3}\right], 31.\right]$ (t $\left.\mathrm{ArCH}_{2} \mathrm{Ar}\right), 23.7\left(\mathrm{t}, \mathrm{OCH}_{2} \mathrm{CH}_{2} \mathrm{CH}_{3}\right), 15.7\left(\mathrm{q}, \mathrm{SCH}_{3}\right) ; \mathrm{FAB}$ mass spectrum (PEG), $m / e$ 880.3 $\left(\mathrm{M}^{+}\right.$, calcd 880.5). Anal. Calcd for $\mathrm{C}_{56} \mathrm{H}_{80} \mathrm{O}_{4} \mathrm{~S}_{2}: \mathrm{C}, 76.31 ; \mathrm{H}, 9.15$. Found: $\mathrm{C}, 75.91 ; \mathrm{H}, 8.97$.

25,27-Bis (diethoxyphosphonoxy)-5,11,17,23-tetrakis (1,1-dimethylethyl)-26,28-dihydroxycalix[4]arene (7). A suspension of calix [4]arene $6(5.0 \mathrm{~g}, 11.78 \mathrm{mmol}), \mathrm{K}_{2} \mathrm{CO}_{3}(1.63 \mathrm{~g}, 11.78 \mathrm{mmol})$, and diethyl chlorophosphate $(5.08 \mathrm{~g}, 29.44 \mathrm{mmol})$ in $\mathrm{CH}_{3} \mathrm{CN}(125 \mathrm{~mL})$ was heated overnight at reflux temperature. Subsequently, the solvent was removed under reduced pressure, and the residue was taken up in $\mathrm{CH}_{2} \mathrm{Cl}_{2}(200$ $\mathrm{mL})$ and washed with water $(200 \mathrm{~mL})$ and brine $(200 \mathrm{~mL})$. The organic phase was dried over $\mathrm{MgSO}_{4}$, and the solvent was removed under reduced pressure. Purification by column chromatography $\left(\mathrm{SiO}_{2}, \mathrm{CH}_{2} \mathrm{Cl}_{2} / \mathrm{Et}\right.$ $\mathrm{OAc} 9: 1$ ) afforded 7 as a white powder $(6.81 \mathrm{~g}, 83 \%)$ : mp $226-229^{\circ} \mathrm{C}$ (McOH); ${ }^{1} \mathrm{H}$ NMR $87.13(\mathrm{~d}, 4 \mathrm{H}, J=7.5 \mathrm{~Hz}, \mathrm{ArH}), 6.85-6.6(\mathrm{~m}, 8$ $\mathrm{H}, \mathrm{ArH}), 5.49(\mathrm{~s}, 2 \mathrm{H}, \mathrm{OH}), 4.47$ and $3.46(\mathrm{ABq}, 8 \mathrm{H}, J=14.2 \mathrm{~Hz}$, $\left.\mathrm{ArCH}_{2} \mathrm{Ar}\right), 4.4-4.15\left[\mathrm{~m}, 8 \mathrm{H}, \mathrm{P}(\mathrm{O}) \mathrm{OCH}_{2} \mathrm{CH}_{3}\right], 1.4-1.3[\mathrm{~m}, 12 \mathrm{H}, \mathrm{P}$. (O) $\left.\mathrm{CH}_{2} \mathrm{CH}_{3}\right] ;{ }^{13} \mathrm{C}$ NMR $\delta 152.8$ (s, Ar 26,28-C), 144.7, 144.6 (s, Ar $25,27-\mathrm{C}), 132.3,132.2,129.2,128.4$ (s, Ar 1,3,7,9,13,15,19,21-C), 129.3, $128.9,125.9,119.7$ (d, all ArC-H), 65.1, $65.0\left(\mathrm{t}, \mathrm{OCH}_{2} \mathrm{CH}_{3}\right), 31.9(\mathrm{t}$, $\left.\mathrm{ArCH}_{2} \mathrm{Ar}\right), 16.2,16.1\left(\mathrm{q}, \mathrm{OCH}_{2} \mathrm{CH}_{3}\right) ; \mathrm{FAB}$ mass spectrum (NBA), $m / e$ $697.1\left[(\mathrm{M}+\mathrm{H})^{+}\right.$, calcd 697.2]. Anal. Calod for $\mathrm{C}_{36} \mathrm{H}_{42} \mathrm{O}_{10} \mathrm{P}_{2}: \mathrm{C}, 62.07 \mathrm{i}$ $\mathrm{H}, 6.08$. Found: $\mathrm{C}, 61.96 ; \mathrm{H}, 6.18$.

25,27-Dibydroxycalix[4/arene (8). Potassium (0.55 $8,14.1 \mathrm{mmol})$ was added (carefully!) in small pieces to liquid ammonia $(60 \mathrm{~mL})$. Subsequently, a solution of diphosphorylated calix[4]arene $7(1.60 \mathrm{~g}, 2.30$ mmol) in THF ( $25 \mathrm{~mL}$ ) was added in small portions over a period of 15 min. After the addition was complete, the mixture was stirred for $1 \mathrm{~h}$. The reaction was quenched with $\mathrm{NH}_{4} \mathrm{Cl}(0.25 \mathrm{~g})$, and the $\mathrm{NH}_{3}$ was allowed to evaporate. The solvent was removed under reduced pressure, and the residue was taken up in $\mathrm{CH}_{2} \mathrm{Cl}_{2}(200 \mathrm{~mL})$. The organic phase was washed with $2 \mathrm{~N} \mathrm{HCl}(200 \mathrm{~mL})$, water $(100 \mathrm{~mL})$, and brine (100 $\mathrm{mL}$ ) and was dried over $\mathrm{MgSO}_{4}$, The solvent was removed under reduced pressure. The product was crystallized from petroleum ether to give 8 as a white powder $(0.81 \mathrm{~g}, 90 \%)$ : $\mathrm{mp} 208-210^{\circ} \mathrm{C}\left(\mathrm{CH}_{2} \mathrm{Cl}_{2}\right.$ $\mathrm{MeOH}){ }^{1} \mathrm{H}$ NMR 8 7.25-7.1 (m, $6 \mathrm{H}$, Ar 4,5,6,16,17,18-H), 7.02 (d, $4 \mathrm{H}, J=7.4 \mathrm{~Hz}$, Ar $10,12,22,24-\mathrm{H}), 6.80(\mathrm{t}, 2 \mathrm{H}, J=7.4 \mathrm{~Hz}, \mathrm{Ar}$ $5,23-\mathrm{H}), 6.44(\mathrm{~s}, 2 \mathrm{H}, \operatorname{Ar} 26,28-\mathrm{H}), 4,19(\mathrm{~s}, 2 \mathrm{H}, \mathrm{OH}), 3.88(\mathrm{~s}, 8 \mathrm{H}$, $\left.\mathrm{ArCH}_{2} \mathrm{Ar}\right) ;{ }^{13} \mathrm{C}$ NMR $\delta 152.2(\mathrm{~s}, \mathrm{Ar} 25,27-\mathrm{C}), 140.7,126.6(\mathrm{~s}, \mathrm{Ar}$ $1,3,7,9,13,15,19,21-C), 130.1,128,6,126.8,126.1,120.4$ (d, all ArC-H), $36.9\left(\mathrm{t}, \mathrm{ArCH}_{2} \mathrm{Ar}\right) ; \mathrm{FAB}$ mass spectrum (NBA), m/e $392.2\left(\mathrm{M}^{+}\right.$, caled 392.2). Anal. Caled for $\mathrm{C}_{28} \mathrm{H}_{24} \mathrm{O}_{2} \cdot 0.15 \mathrm{CH}_{2} \mathrm{Cl}_{2} ; \mathrm{C}, 83.54 ; \mathrm{H}, 6.07$. Found: $\mathrm{C}, 83.42 ; \mathrm{H}, 6.04$

25,27-Bis[(2-methylthio)ethoxy]callx $[4$ 4)arene (9), A suspension of dihydroxycalix [4]arene $8(1.00 \mathrm{~g}, 2.55 \mathrm{mmol})$ and $\mathrm{NaH}[0.76 \mathrm{~g}, 25.5$ mmol; freed from mineral oil by washing with petroleum ether (bp 40-60 $\left.\left.{ }^{\circ} \mathrm{C}\right)(2 \times 5 \mathrm{~mL})\right]$ in DMF $(25 \mathrm{~mL})$ was stirred at room temperature for $1 \mathrm{~h}$. Subsequently, 2-chloroethyl methyl sulfide $(5.63 \mathrm{~g}, 50.9 \mathrm{mmol})$ was added, and the reaction mixture was stirred at $55^{\circ} \mathrm{C}$ overnight. After cooling to room temperature, the solvent was removed under reduced pressure. The oily residue was taken up in $\mathrm{CH}_{2} \mathrm{Cl}_{2}(150 \mathrm{~mL})$ and was washed with saturated $\mathrm{NH}_{4} \mathrm{Cl}(4 \times 150 \mathrm{~mL})$, followed by brine $(100$ $\mathrm{mL}$ ). The organic layer was dried with $\mathrm{MgSO}_{4}$, and the solvent was evaporated. The crude oil was crystallized with diethyl ether, and the resulting solid was purified by column chromatography ( $\mathrm{SiO}_{2}, \mathrm{CH}_{2} \mathrm{Cl}_{2}$ ) to yield 9 as a white powder $(0.79 \mathrm{~g}, 37 \%)$ : mp $145-148{ }^{\circ} \mathrm{C}$ $\left(\mathrm{CH}_{2} \mathrm{Cl}_{2} / \mathrm{MeOH}\right) ;{ }^{1} \mathrm{H}$ NMR $87.25-7.1(\mathrm{~m}, 6 \mathrm{H}$, Ar 4,5,6,16,17,18-H), $7.0-6.9(\mathrm{~m}, 6 \mathrm{H}, \operatorname{Ar} 10,11,12,22,23,24-\mathrm{H}), 6.57(\mathrm{~s}, 2 \mathrm{H}, \mathrm{Ar} 26,28-\mathrm{H})$, 4.27 and $3.63\left(\mathrm{ABq}, 8 \mathrm{H}, J=14.9 \mathrm{~Hz}, \mathrm{ArCH}_{2} \mathrm{Ar}\right), 3.29(\mathrm{t}, 4 \mathrm{H}, J=6.4$ $\left.\mathrm{Hz}, \mathrm{OCH}_{2}\right), 2.39\left(\mathrm{t}, 4 \mathrm{H}, J=6.4 \mathrm{~Hz}_{1} \mathrm{CH}_{2} \mathrm{~S}\right), 1.81\left(\mathrm{~s}, 6 \mathrm{H}_{1}, \mathrm{SCH}_{3}\right){ }^{13} \mathrm{C}$ NMR $\delta 154.7$ (s, Ar 25,27-C), 142.3, 134.0 (s, Ar 1,3,7,9,13,15,19,21-C), $129.8,128.2,127.8,125.8,124.3($ d, all $A r C-H), 72.8\left(t, O_{2} C_{2}\right), 35.3$ 
(t. $\left.\mathrm{CH}_{2} \mathrm{~S}\right), 33.6\left(\mathrm{t}, \mathrm{ArCH}_{2} \mathrm{Ar}\right), 15.8\left(\mathrm{q}, \mathrm{SCH}_{3}\right) ; \mathrm{FAB}$ mass spectrum (NBA), m/e 542.2 [(M $+2 \mathrm{H})^{+}$, calcd 542.2]. Anal. Calcd for $\mathrm{C}_{34} \mathrm{H}_{36} \mathrm{O}_{2} \mathrm{~S}_{2}: \mathrm{C}, 74.56 ; \mathrm{H}, 6.64$. Found: $\mathrm{C}, 74.57 ; \mathrm{H}, 6.87$.

Reduction of Tetraester p-tert-Butylcallx[4]arene 10 and Diester p. tert-Butylcallix[4]arease 14 with LiAlH, 4 . Formation of 11 and 15. To a solution of calix [4] arenes 10 and 14 (13.6 mmol) in diethyl ether (250 $\mathrm{mL}$ ) was added $\mathrm{LiAlH}_{4}(4.23 \mathrm{~g}, 111.5 \mathrm{mmol})$ in small portions at $10^{\circ} \mathrm{C}$ and the mixture was stirred overnight at room temperature. $\mathrm{HCl}(2 \mathrm{~N})$ was added (carefully!) in small portions until a firm precipitate had formed, and the diethyl ether was decanted. The precipitate was treated with another portion of diethyl ether $(250 \mathrm{~mL})$, and the combined organic layers were dried over $\mathrm{MgSO}_{4}$. The solvent was evaporated, and the crude product was recrystallized from $\mathrm{CH}_{2} \mathrm{Cl}_{2} / \mathrm{MeOH}$ to give pure $\mathbf{1 1}$ and 15 as white crystals.

5,11,17,23-Tetrakis(1,1-dimethylethyl)-25,26,27,28-tetrakis (bydroxyethoxy)callix (4)arene (11): yield $86 \% ; \mathrm{mp}>270^{\circ} \mathrm{C}$ dec; ${ }^{\prime} \mathrm{H}$ NMR $\delta 6.85$ (s, $8 \mathrm{H}, \mathrm{ArH}), 5.14\left(\mathrm{t}, 4 \mathrm{H}, J=5.4 \mathrm{~Hz}_{1} \mathrm{ArOCH}_{2} \mathrm{CH}_{2} \mathrm{OH}\right), 4.35$ and 3.23 $\left(\mathrm{ABq}, 8 \mathrm{H}, J=12.7 \mathrm{~Hz}, \mathrm{ArCH}_{2} \mathrm{Ar}\right), 4.1-3.9\left(\mathrm{~m}, 16 \mathrm{H}, \mathrm{ArOCH}_{2} \mathrm{CH}_{2^{-}}\right.$ $\mathrm{OH}$ and $\left.\mathrm{ArOCH} \mathrm{CH}_{2} \mathrm{OH}\right), 1.09\left[\mathrm{~s}, 36 \mathrm{H}, \mathrm{C}\left(\mathrm{CH}_{3}\right)_{3}\right]{ }^{13} \mathrm{C}$ NMR $\delta 152.3$ (s, Ar 25,26,27,28-C), 145.7 (s, Ar-5,11,17,23-C), 133.5 (s, Ar 1,3,7,9,13,15,19,21-C), 125.5 (d, all AtC- $\mathrm{H}), 77,8\left(\mathrm{t}, \mathrm{ArOCH}, \mathrm{CH}_{2} \mathrm{OH}\right.$ ) $61.7\left(\mathrm{t}, \mathrm{ArOCH} \mathrm{CH}_{2} \mathrm{OH}\right), 33.9\left[\mathrm{q}_{1} \mathrm{C}\left(\mathrm{CH}_{3}\right)_{3}\right], 31.4\left[\mathrm{~s}, \mathrm{C}\left(\mathrm{CH}_{3}\right)_{3}\right], 30.4$ $(t, A r C H, A r) ; F A B$ mass spectrum (NBA), m/e $825.8\left[(\mathrm{M}+\mathrm{H})^{+}\right.$, calcd 825.5]. Anal. Caled for $\mathrm{C}_{52} \mathrm{H}_{72} \mathrm{O}_{8}, 0.1 \mathrm{CH}_{2} \mathrm{Cl}_{2} ; \mathrm{C}, 75.07 ; \mathrm{H}, 8.73$. Found: $C, 75.16 ; \mathrm{H}, 9.03$.

5,11,17,23-Tetrakls(1,1-dimethylethyl)-25,27-bis (hydroxyethoxy)26,28-dlpropoxycalix[4]arene (15); yield $75 \%$; mp $223-226{ }^{\circ} \mathrm{C}$; ${ }^{1} \mathrm{H}$ NMR $87.16,6.49(\mathrm{~s}, 4 \mathrm{H}, \mathrm{ArH}), 5.08(\mathrm{bs}, 2 \mathrm{H}, \mathrm{OH}), 4.36$ and 3.19 $\left(\mathrm{ABq}, 8 \mathrm{H}, J=12.7 \mathrm{~Hz}, \mathrm{ArCH}_{2} \mathrm{Ar}\right), 4.2-4.1(\mathrm{~m}, 4 \mathrm{H}$, ArOCH $\left.\mathrm{CH}_{2} \mathrm{OH}\right), 4.1-4.0\left(\mathrm{~m}, 4 \mathrm{H}, \mathrm{ArOCH} \mathrm{CH}_{2} \mathrm{OH}\right), 3.74(\mathrm{t}, 4 \mathrm{H}, J$ $\left.=7.8 \mathrm{~Hz}, \mathrm{ArOCH}_{2} \mathrm{CH}_{2} \mathrm{CH}_{3}\right), 1.95-1.8\left(\mathrm{~m}_{1} 4 \mathrm{H}, \mathrm{ArOCH}_{2} \mathrm{CH}_{2} \mathrm{CH}_{3}\right)$, $1,35,0.83\left[s, 18 \mathrm{H}, \mathrm{C}\left(\mathrm{CH}_{3}\right)_{3}\right], 0.94\left(\mathrm{t}_{1} 6 \mathrm{H}, J=7.4 \mathrm{~Hz}_{1}\right.$ $\mathrm{ArOCH}_{2} \mathrm{CH}_{2} \mathrm{CH}_{3}$ ); ${ }^{3} \mathrm{C}$ NMR $\delta$ 1 $153,8,151.2$ (s, Ar 25,26,27,28-C), $145.6,144.7$ (s, Ar $5,11,17,23-\mathrm{C}), 135.6,131.8$ (s, Ar $1,3,7,9,13,15,19,21-\mathrm{C}), 125,8,124,8$ (d, all ArC-H), 78.5 (t, ArOCH ${ }_{2} \mathrm{CH}_{2} \mathrm{OH}$ ), 77.0 ( $\mathrm{t}$, ArOC $\left.\mathrm{CH}_{2} \mathrm{CH}_{2} \mathrm{CH}_{3}\right), 61.7$ (t, ArOCH $\left.{ }_{2} \mathrm{CH}_{2} \mathrm{OH}\right), 34.1,33.6\left[\mathrm{~s}, \mathrm{C}\left(\mathrm{CH}_{3}\right), 3,31.7,31.1\left[\mathrm{q}, \mathrm{C}\left(\mathrm{CH}_{3}\right)\right], 30.8\right.$ (t, $\mathrm{ArCH} 2 \mathrm{Ar}), 22.6\left(\mathrm{t}, \mathrm{ArOCH} \mathrm{CH}_{2} \mathrm{CH}_{3}\right), 10.2\left(\mathrm{q}, \mathrm{ArOCH} \mathrm{CH}_{2} \mathrm{CH}_{3}\right)$; FAB mass spectrum (NBA), $m / e$ 821.6 [( $\mathrm{M}+\mathrm{H})^{+}$, calcd 821.6]. Anal. Calcd for $\mathrm{C}_{54} \mathrm{H}_{76} \mathrm{O}_{6} \cdot 0.15 \mathrm{CH}_{2} \mathrm{Cl}_{2}: \mathrm{C}, 77.99 ; \mathrm{H}, 9.22$. Found: $\mathrm{C}_{1} 77.98$; $\mathrm{H}, 9.50$.

Tosylation of Tetrakls (2-hydroxyethoxy)-p-tert-butylcalix[4]arene 11 and Bis (2-bydroxyethoxy)-p-tert-butylcalix[4] herene 15. Formation of 12 and 16. To a solution of the calix [4]arenes 11 and $15(1.2 \mathrm{mmol})$ in pyridine $(25 \mathrm{~mL})$ was added $p$-toluenesulfonyl chloride $(14.5 \mathrm{mmol}$ in the case of $11 ; 6.0 \mathrm{mmol}$ in the case of 15 ) at $0^{\circ} \mathrm{C}$, wheroupon the homogeneous solution was stored in the refrigerator at $4^{\circ} \mathrm{C}$ for 4 days. The reaction mixture was poured into ice-cold $2 \mathrm{~N} \mathrm{HCl}(250 \mathrm{~mL})$, and the precipitate was collected by filtration. The solid was dissolved in $\mathrm{CH}_{2} \mathrm{Cl}_{2}(200 \mathrm{~mL})$ and washed successively with $\mathrm{HCl}(200 \mathrm{~mL})$ and brine $(100 \mathrm{~mL})$. After drying over $\mathrm{MgSO}_{4}$, the solvent was evaporated under reduced pressure to give 12 and 16, which were pure enough for further reactions.

$5,11,17,23-$ Tetrakis (1,1-dimethylethyl)-25,26,27,28-tetrakis $(((4$ methylphenyl)sulfonyl) oxy)ethoxy]callx(4)arene (12): yield $85 \%$; ${ }^{\prime} \mathrm{H}$ NMR $87,80,7.33\left(\mathrm{~d}, 8 \mathrm{H}, J=8.2 \mathrm{~Hz}, \mathrm{SO}_{3} \mathrm{ArH}\right), 6.70(\mathrm{~s}, 8 \mathrm{H}, \mathrm{Ar}$ $4,6,10,12,16,18,22,24-\mathrm{H}), 4.45-4.35\left(\mathrm{~m}, 8 \mathrm{H}, \mathrm{ArOCH}_{2}\right), 4.22$ and 3.00 (ABq, $\left.8 \mathrm{H}, J=12.8 \mathrm{~Hz}, \mathrm{ArCH}{ }_{2} \mathrm{Ar}\right), 4.15-4.05\left(\mathrm{~m}, 8 \mathrm{H}, \mathrm{ArOCH} \mathrm{CH}_{2}\right)$, $2.44\left(\mathrm{~s}, 12 \mathrm{H}, \mathrm{OSO}_{2} \mathrm{ArCH}_{3}\right), 1.05\left[\mathrm{~s}, 36 \mathrm{H}, \mathrm{C}\left(\mathrm{CH}_{3}\right)_{3}\right] ;{ }^{13} \mathrm{C}$ NMR $\delta 152,1$ (s, Ar 25,26,27,28-C), 145,2, 144,8 (s, Ar 5,11,17,23-C and ArC-SO, 133.4, 133.0 (s, Ar 1,3,7,9,13,15,19,21-C and O,SArC-CH, 129.9 , 128.0 (d, O,SArC-H), 125.2 (d, Ar 4,6,10,12,16,18,22,24-C-H), 71.6, 69.5 (t, ArOCH $\mathrm{CH}_{2}$ and $\left.\mathrm{ArOCH}{ }_{2} \mathrm{CH}_{2}\right), 33,8\left[\mathrm{~s}, \mathrm{C}\left(\mathrm{CH}_{3}\right)_{3}\right], 31,4$ [q, $\mathrm{C}(\mathrm{CH}), 3,31.0(\mathrm{t}, \mathrm{ArCH}, \mathrm{Ar}), 21.7\left(\mathrm{q}, \mathrm{Ar}-\mathrm{CH}_{3}\right) ; \mathrm{FAB}$ mass spectrum (NBA), $m / e$ 1440.6 $\left(\mathrm{M}^{+}\right.$, calcd for $\left.\mathrm{C}_{30} \mathrm{H}_{96} \mathrm{O}_{16} \mathrm{~S}_{4}, 1440.3\right)$

$5,11,17,23-T$ etrakis (1,1-dimethylettyl) $)-25,27 \cdot b i s[((4$-methylphenyl) sulfonyl)oxy)ethoxy\}-26,28-dlpropoxycallx [4]arene (16); yield 83\%; 'H NMR $87.79,7.35\left(\mathrm{~d}, 4 \mathrm{H}, J=8.2 \mathrm{~Hz}, \mathrm{SO}_{3} \mathrm{ArH}\right), 7.01,6.46(\mathrm{~s}, 4 \mathrm{H}$, $\mathrm{ArH}), 4.61\left(\mathrm{t}, 4 \mathrm{H}, J=6.2 \mathrm{~Hz}, \mathrm{ArOCH}_{2} \mathrm{CH}_{2} \mathrm{OSO}_{2}\right), 4.22(\mathrm{t}, 4 \mathrm{H}, J=$ $\left.6.2 \mathrm{~Hz}, \mathrm{ArOCH} \mathrm{CH}_{2} \mathrm{OSO}_{2}\right), 4.21$ and $3.07(\mathrm{ABq}, 8 \mathrm{H}, J=12.7 \mathrm{~Hz}$ $\mathrm{ArCH}, \mathrm{Ar}), 3.60\left(\mathrm{t}, 4 \mathrm{H}, J=7.7 \mathrm{~Hz}, \mathrm{ArOCH} \mathrm{CH}_{2} \mathrm{CH}_{3}\right), 2.46(\mathrm{~s}, 6 \mathrm{H}$ O, $\left.\mathrm{SArCH}_{3}\right), 1.85-1.7\left(\mathrm{~m}, 4 \mathrm{H}, \mathrm{Ar} \mathrm{OCH}_{2} \mathrm{CH}_{2} \mathrm{CH}_{3}\right), 1.28,0.83[\mathrm{~s}, 18 \mathrm{H}$, $\left.\mathrm{C}\left(\mathrm{CH}_{3}\right)_{3}\right), 0.91\left(\mathrm{t}, 6 \mathrm{H}_{1} J=7.4 \mathrm{~Hz} \text {, ArOCH}{ }_{2} \mathrm{CH}_{2} \mathrm{CH}_{3}\right)_{i}{ }^{13} \mathrm{C}$ NMR $\delta$ $153.3,152.2$ (s, At 25,26,27,28-C), 145.5, 144.6, 144.2 (s, Ar $5,11,17,23 \cdot \mathrm{C}$ and ArC-SO $), 135.0,133.4,132.0$ (s, Ar $1,3,7,9,13,15,19,21 \cdot \mathrm{C}$ and $\left.\mathrm{ArC} \cdot \mathrm{CH}_{3}\right), 129.9,127.9$ (d, O,SArC-H) $125.5,124.6$ (d, Ar $4,6,10,12,16,18,22,24-\mathrm{C} \cdot \mathrm{H}$ ), 77.7 (t ArOCH $\left.\mathrm{CH}_{2} \mathrm{CH}_{3}\right), 70.6,69.1$ (t, $\mathrm{ArOCH}_{2} \mathrm{CH}_{2} \mathrm{OSO}_{2}$ and ArOCH $\left.2 \mathrm{CH}_{2} \mathrm{OSO}_{2}\right), 34.1,33.6\left[\mathrm{~s}, \mathrm{C}\left(\mathrm{CH}_{3}\right)_{3}\right], 31.7,31.1\left(\mathrm{q}, \mathrm{C}\left(\mathrm{CH}_{3}\right)_{3}\right]$, $31.0\left(t_{1} \mathrm{ArCH}_{2} \mathrm{Ar}\right), 23.2\left(\mathrm{t}, \mathrm{ArOCH}_{2} \mathrm{CH}_{2} \mathrm{CH}_{3}\right), 21.7\left(q, \mathrm{ArCH}_{3}\right), 10.4$ (q, $\left.\mathrm{ArOCH}_{2} \mathrm{CH}_{2} \mathrm{CH}_{3}\right)$; FAB mass spectrum (NBA), m/e $1128.3\left(\mathrm{M}^{+}\right.$, calcd for $\mathrm{C}_{68} \mathrm{H}_{88} \mathrm{O}_{10} \mathrm{~S}_{2}$ !128,6).

Renction of Tetraklis:(((4-methylphenyl) sulfonyl)oxy)ethoxyy-p-tert butylcallix[4]arene 12 and Bla[(((4-methylphenyl) sulfonyl) oxy)ethoxy\} $p$ tert-butylcalix[4]arene 16 with Sodium $N, N$.Diethyl Dithiocarbenic Acid Tribydrate. Formation of 13 and 17. A mixture of [(tosyloxy)ethoxy]-p-tert-butylcalix [4] arenes 12 and $16(2.5 \mathrm{mmol})$ and sodium $N, N$. diethyl dithiocarbamic acid trihydrate $(2.48,11.0 \mathrm{mmol}$ in the case of $12 ; 1.24 \mathrm{~g}, 5.5 \mathrm{mmol}$ in the case of 16$)$ in acetone $(20 \mathrm{~mL})$ was stirred overnight at reflux temperature. The solvent was removed under reducod pressure. The residue was taken up in $\mathrm{CH}_{2} \mathrm{Cl}_{2}$ (200 mL), washed with water $(2 \times 50 \mathrm{~mL})$ and brine $(50 \mathrm{~mL})$, and dried over $\mathrm{MgSO}_{4}$. The solvent was removed under reduced pressure.

25,26,27,28-Tetrakis[(dlethyldithjocarbamoyl)ethoxy]-5,11,17,23-tetrakjs(1,1-dlmethylethyl)callx[4]arene (13). The crude product was purified by column chromatography $\left(\mathrm{SiO}_{2}, \mathrm{CH}_{2} \mathrm{Cl}_{2}\right)$ : yield $72 \%$; $\mathrm{mp}$ 174-175 ${ }^{\circ} \mathrm{C}\left(\mathrm{CH}_{2} \mathrm{Cl}_{2} / \mathrm{MeOH}\right)$; ' $\mathrm{H}$ NMR $86.77(\mathrm{~s}, 8 \mathrm{H}, \mathrm{ArH}), 4.53$ and $3.18\left(\mathrm{ABq}, 8 \mathrm{H}, J=12.7 \mathrm{~Hz}, \mathrm{ArCH}_{2} \mathrm{Ar}\right), 4.26(\mathrm{t}, 8 \mathrm{H}, J=6.7 \mathrm{~Hz}$, ArOCH $\left.\mathrm{CH}_{2}\right), 4.1-3.95\left(\mathrm{~m}, 16 \mathrm{H}_{1}\right.$ ArOCH${ }_{2} \mathrm{CH}_{2}$ and $\left.\mathrm{NCH}_{2}\right), 3.76(\mathrm{q}$, $\left.8 \mathrm{H}_{1} J=6.9 \mathrm{~Hz}, \mathrm{NCH}_{2}\right), 1.35-1.2\left(\mathrm{~m}, 24 \mathrm{H}_{1} \mathrm{NCH}_{2} \mathrm{CH}_{3}\right), 1.07[\mathrm{~s}, 36$ $\left.\mathrm{H}, \mathrm{C}\left(\mathrm{CH}_{3}\right)_{3}\right] ;{ }^{13} \mathrm{C}$ NMR 8 195.5 (s, C-S), $153.0(\mathrm{~s}, \mathrm{Ar} 25,26,27,28-\mathrm{C}$ ), $144.6(\mathrm{~s}, \operatorname{Ar} 5,11,17,23-\mathrm{C}), 133.7(\mathrm{~s}, \operatorname{Ar} 1,3,7,9,13,15,19,21-\mathrm{C}), 125.0$ (d, all ArC-H), $73.4\left(t, \mathrm{ArOCH}_{2}\right), 49.5,46.8\left(t, \mathrm{NCH}_{2}\right), 36.6\left(t, \mathrm{CH}_{2} \mathrm{~S}\right)$, $33.8\left[\mathrm{~s}, \mathrm{C}\left(\mathrm{CH}_{3}\right)_{3}\right], 31.4\left[\mathrm{q}+\mathrm{t}, \mathrm{C}\left(\mathrm{CH}_{3}\right)_{3}\right.$ and $\left.\mathrm{ArCH}_{2} \mathrm{Ar}\right], 12.6,11.7(\mathrm{q}$, $\left.\mathrm{NCH}_{2} \mathrm{CH}_{3}\right) ; \mathrm{FAB}$ mass spectrum $(\mathrm{NBA}), m / e 1348.6\left[(\mathrm{M}+\mathrm{H})^{+}\right.$, calcd 1348.3]. Anal, Caled for $\mathrm{C}_{72} \mathrm{H}_{108} \mathrm{~N}_{1} \mathrm{O}_{4} \mathrm{~S}_{8}: \mathrm{C}, 64.05 ; \mathrm{H}, 8.06 ; \mathrm{N}, 4,15$; $S, 19.00$. Found: $C, 63.94 ; \mathrm{H}, 8,12 ; \mathrm{N}, 4.07 ; \mathrm{S}, 18.83$,

25,27-Bis[(diethyldithiocarbamoyl)ethoxy\}5,11,17,23-tetrakds(1,1-dimethylethyl)-26,28-dipropoxycallx[4]arene (17). The crude product was triturated with MeOH: yield $90 \%$; mp $235-236^{\circ} \mathrm{C}\left(\mathrm{CH}_{2} \mathrm{Cl} / \mathrm{MeOH}\right)$; ${ }^{1} \mathrm{H}$ NMR $86.78,6.77(\mathrm{~s}, 4 \mathrm{H}, \mathrm{ArH}), 4.46$ and $3.14(\mathrm{ABq}, 8 \mathrm{H}, J=12.6$ $\left.\mathrm{Hz}, \mathrm{ArCH} \mathrm{Ar}_{2}\right), 4.18\left(t, 4 \mathrm{H}, J=6.9 \mathrm{~Hz}, \mathrm{ArOCH}_{2} \mathrm{CH}_{2} \mathrm{~S}\right), 4.03,3.76$ (q, $\left.4 \mathrm{H}, J=7.0 \mathrm{~Hz}, \mathrm{NCH}_{2}\right), 4.0-3.85\left(\mathrm{~m}, 8 \mathrm{H}, \mathrm{ArOCH}_{2} \mathrm{CH}_{2} \mathrm{CH}_{3}\right.$ and ArOCH $\left.\mathrm{CH}_{3} \mathrm{~S}\right), 2.2-2.0\left(\mathrm{~m}, 4 \mathrm{H}, \mathrm{ArOCH} \mathrm{CH}_{2} \mathrm{CH}_{3}\right), 1.35-1.25(\mathrm{~m}, 12$ $\left.\mathrm{H}, \mathrm{NCH}_{2} \mathrm{CH}_{3}\right), 1.08,1.06\left[s, 18 \mathrm{H}, \mathrm{C}\left(\mathrm{CH}_{3}\right)\right], 0.98(t, 6 \mathrm{H}, J=7,5 \mathrm{~Hz}$, ArOCH $\left.{ }_{2} \mathrm{CH}_{2} \mathrm{CH}_{3}\right) ;{ }^{13} \mathrm{C}$ NMR $\delta 195.5(\mathrm{~s}, \mathrm{C}=\mathrm{S}), 153.6,153.1$ (s, Ar $25,26,27,28-\mathrm{C}), 144,6,144,2$ (s, Ar 5,11,17,23-C), 133.81, 133.76 (s, Ar $1,3,7,9,13,15,19,21-C), 125.0,124.9$ (d, all ArC-H), 77.3 (t, ArOCH $\left.\mathrm{CH}_{2} \mathrm{CH}_{3}\right), 73.1\left(t_{1} \mathrm{ArOCH} \mathrm{CH}_{2} \mathrm{~S}\right), 49.6,46.7\left(t, \mathrm{NCH}_{2}\right), 36.4$ (t, ArOCH $\left.\mathrm{CH}_{2} \mathrm{~S}\right), 33.84,33,81\left[\mathrm{~s}, \mathrm{C}\left(\mathrm{CH}_{3}\right)_{3}\right], 31.5\left[\mathrm{q}, \mathrm{C}\left(\mathrm{CH}_{3}\right)_{3}\right], 31.3$ $\left(t, \mathrm{ArCH}_{2} \mathrm{Ar}\right), 23.5\left(\mathrm{t}, \mathrm{ArOCH}_{2} \mathrm{CH}_{2} \mathrm{CH}_{3}\right),\left[2.5,11.6\left(\mathrm{q}, \mathrm{NCH}_{2} \mathrm{CH}_{3}\right)\right.$, $10.4\left(q_{1}\right.$ ArOCH $\left.{ }_{2} \mathrm{CH}_{2} \mathrm{CH}_{3}\right)$; FAB mass spectrum (NBA), $\mathrm{m} / \mathrm{e} 1082.5$ $\left(\mathrm{M}^{+}\right.$, calcd 1082.6). Anal. Caled for $\mathrm{C}_{64} \mathrm{H}_{94} \mathrm{~N}_{2} \mathrm{O}, \mathrm{S}_{4}: \mathrm{C}, 70.93 ; \mathrm{H}, 8.74 ;$ $\mathrm{N}, 2.58 ; \mathrm{S}, 11.83$. Found: $\mathrm{C}, 70.76 ; \mathrm{H}, 9.12 ; \mathrm{N}, 2.49 ; \mathrm{S}, 11.79$.

5,11,17,23-Tetrakls (1,1-dlmethylethyl)-25,27-bis[(ethoxycarbonyl)methoxy]-26,28-dipropoxycalix[4]arene (14). A suspension of dihydroxydipropoxy-p.tert-butylcalix[4]arene $4(12.78,17.43 \mathrm{mmol})$ and $\mathrm{NaH}[2.61 \mathrm{~g}, 87.16 \mathrm{mmol}$; freed from mineral oil by washing with petroleum ether (bp 40-60 $\left.\left.{ }^{\circ} \mathrm{C}\right)(2 \times 15 \mathrm{~mL})\right]$ in DMF $(250 \mathrm{~mL})$ was stirred for $\mathrm{l} h$ at room temperature. Subsequently, ethyl bromoacetate $(14.56 \mathrm{~g}, 87.16 \mathrm{mmol}$ ) was added, and the mixture was stirred overnight at $60^{\circ} \mathrm{C}$. The solvent was removed under reduced pressure, and the residue was taken up in $\mathrm{CH}_{2} \mathrm{Cl}_{2}(200 \mathrm{~mL})$. After washing with saturated $\mathrm{NH}_{4} \mathrm{Cl}(4 \times 250 \mathrm{~mL})$, followed by brine $(200 \mathrm{~mL})$ the organic layer was dried over $\mathrm{MgSO}_{4}$. The solvent was eyaporated and the crude product was crystallized from $\mathrm{MeOH}$. Recrystallization from $\mathrm{CH}_{2} \mathrm{Cl}_{2} / \mathrm{MeOH}$ afforded pure $14(13.30 \mathrm{~g}, 84 \%)$ as white crystals: $\mathrm{mp} 189-190^{\circ} \mathrm{C} ;{ }^{\prime} \mathrm{H}$ NMR $\delta 6.86,6.68(s, 4 \mathrm{H}, \mathrm{ArH}), 4.79\left[\mathrm{~s}, 4 \mathrm{H}, \mathrm{ArOCH}_{2} \mathrm{C}(\mathrm{O})\right], 4.62$ and $3.17(\mathrm{ABq}, 8 \mathrm{H}, J=12.8 \mathrm{~Hz}, \mathrm{ArCH}, \mathrm{Ar}), 4.21[\mathrm{q}, 4 \mathrm{H}, J=7.1 \mathrm{~Hz}$, $\mathrm{C}(\mathrm{O}) \mathrm{OCH}_{2} \mathrm{CH}_{3}$ ) $3.82\left(\mathrm{t}, 4 \mathrm{H}, J=7.5 \mathrm{~Hz}, \mathrm{ArOCH} \mathrm{CH}_{2}\right), 2.05-1.9(\mathrm{~m}$, $\left.4 \mathrm{H}, \mathrm{ArOCH}_{2} \mathrm{CH}\right), 1.28\left[\mathrm{t}, 6 \mathrm{H}, J=7.1 \mathrm{~Hz}, \mathrm{C}(\mathrm{O}) \mathrm{OCH}_{2} \mathrm{CH}_{1}\right), 1.14$, $1,01\left[B_{1} 18 \mathrm{H}_{1} \mathrm{C}\left(\mathrm{CH}_{3}\right)_{3}\right], 1,00\left(\mathrm{t}, 6 \mathrm{H}, J=7,4 \mathrm{~Hz}_{1} \mathrm{OCH}_{2} \mathrm{CH}_{2} \mathrm{CH}_{3}\right) i^{13} \mathrm{C}$ NMR $8170.5(\mathrm{~s}, \mathrm{C}=0), 153.6,152.9(\mathrm{~s}, \mathrm{Ar} 25,26,27,28-\mathrm{C}), 144.9$, 144.3 (s, Ar 5,11,17,23-C), 134.0, 133.1 (s, Ar 1,3,7,9,13,15,19,21-C), 125.4, 124.8 (d, all ArC-H), 77.0 (i, ArOCH $\mathrm{CH}_{2} \mathrm{CH}_{3}$ ), 70.8 [t, ArOCH $\left.{ }_{2} \mathrm{C}(\mathrm{O}) \mathrm{OCH}_{2}\right], 60,4\left[\mathrm{t}, \mathrm{C}(\mathrm{O}) \mathrm{OCH}, \mathrm{CH}_{3}\right], 33.9,33,7\left[\mathrm{~s}, \mathrm{C}\left(\mathrm{CH}_{3}\right)\right]$, $31.7\left(t, \mathrm{ArCH}_{2} \mathrm{Ar}\right), 31,5,31,4\left[\mathrm{q}_{1} \mathrm{C}\left(\mathrm{CH}_{3}\right)_{3}\right] ;$ FAB mass spectrum (NBA), $m / e$ 904.6 $\left(\mathrm{M}^{+}\right.$, calcd 904,6). Anal. Caled for $\mathrm{C}_{88} \mathrm{H}_{80} \mathrm{O}_{8}: \mathrm{C}_{1}$ $76.95 ; \mathrm{H}, 8,91$. Found: $\mathrm{C}, 77.09 ; \mathrm{H}, 9.28$.

26,28-Bis( dimethylcarbamoyl)mothoxy\}-5,11,17,23-tetrakia (1,1-d1methylethyl)-25, 27-dibydroxycallix[4tarene (18). A suspension of $p$ tert-butylcalix [4]arene $1(10.0 \mathrm{~g}, 15.41 \mathrm{mmol}), \mathrm{K}_{2} \mathrm{CO}_{3}(2.13 \mathrm{~g}, 15.41$ mmol), and $N, N$-dimethyl-2-chloroacetamide $(4.12 \mathrm{~g}, 33.89 \mathrm{mmol})$ in $\mathrm{CH}_{3} \mathrm{CN}(250 \mathrm{~mL})$ was heated overnight at reflux temperature. Subsequently the solvent was removed under reduced pressure, and the residue was dissolved in $\mathrm{CH}_{2} \mathrm{Cl} 2(200 \mathrm{~mL})$ and washed with $2 \mathrm{~N} \mathrm{HCl}(200 \mathrm{~mL})$. The organic layer was washed with water $(200 \mathrm{~mL})$ and dried over $\mathrm{MgSO}_{4}$. After evaporation of the solvent the mixture was crystallized from dilisopropyl ether to yield 18 as a white powder $(10.988,87 \%): \mathrm{mp}$ $>250^{\circ} \mathrm{C}$ dec $\left(\mathrm{CH}_{2} \mathrm{Cl}_{2} / \mathrm{MeOH}\right) ;{ }^{1} \mathrm{H}$ NMR $88,08(\mathrm{~s}, 2 \mathrm{H}, \mathrm{OH}), 6.97$, 
$6.94(8,4 \mathrm{H}, \mathrm{ArH}), 4.86\left(\mathrm{~s}, 4 \mathrm{H}, \mathrm{ArOCH}_{2}\right), 4.48$ and $3.30(\mathrm{ABq}, 8 \mathrm{H}$, $\left.J=13.0 \mathrm{~Hz}, \mathrm{ArCH}_{2} \mathrm{Ar}\right), 3.12,3.02\left(\mathrm{~s}, 6 \mathrm{H}, \mathrm{NCH}_{3}\right), 1.18,1.11[\mathrm{~s}, 18$ $\left.\mathrm{H}, \mathrm{C}\left(\mathrm{CH}_{3}\right)_{3}\right] ;{ }^{13} \mathrm{C} \mathrm{NMR}$ o $168.7(\mathrm{~s}, \mathrm{C}=0), 151.8,150.0(\mathrm{~s}, \mathrm{Ar}$ 25,26,27,28-C) 146.9, 141.2 (s, Ar 5,11,17,23-C), 133.3, 127.8 (s, Ar $1,3,7,9,13,15,19,21-\mathrm{C}), 125.6,124.8(\mathrm{~d}$, all $\mathrm{ArC}-\mathrm{H}), 73.7\left(\mathrm{t}, \mathrm{OCH}_{2}\right)$, $36.5,35.6\left(\mathrm{q}, \mathrm{NCH}_{3}\right), 34.0,33.7\left[\mathrm{~s}, \mathrm{C}\left(\mathrm{CH}_{3}\right)_{3}\right], 31.9(\mathrm{t}, \mathrm{ArCH}, \mathrm{Ar}), 31.5$ $31.2\left[q, \mathrm{C}\left(\mathrm{CH}_{3}\right)_{3}\right]$; FAB mass spectrum $(\mathrm{NBA}), m / e 819.5\left(\mathrm{M}^{+}\right.$, calcd 819.5). Anal. Calcd for $\mathrm{C}_{52} \mathrm{H}_{68} \mathrm{~N}_{2} \mathrm{O}_{6} \cdot 0.25 \mathrm{CH}_{2} \mathrm{Cl}_{2}: \mathrm{C}, 74.86 ; \mathrm{H}_{1}, 8.24$; $N$, 3.34. Found: $C, 74.66 ; H, 8.47 ; N, 3.34$.

Reaction of Bis(dimethylcarbamoyl)methoxy\}-p-tert-butylcalix[4]arenes 18 and 20 with Laresson's Reagent. Formation of 19 and 21 . A mixture of calix [4]arenes 18 and $20(1.22 \mathrm{mmol})$ and Lawesson's reagent $(0.52 \mathrm{~g}, 1.28 \mathrm{mmol})$ in toluene $(10 \mathrm{~mL})$ was stirred overnight at $85-90$ 'C. The solvent was evaporated, and the crude product was solidified with $\mathrm{MeOH}$.

5,11,17,23-Tetrakis (1,1-dimethylethyl)-26,28-bis) (dimethyltbiocarbamoyl)methoxy\}-25,27.dihydroxycalix [4\}arene (19). The resulting light-brown powder was purified by column chromatography $\left(\mathrm{SiO}_{2}\right.$, $\left.\mathrm{CH}_{2} \mathrm{Cl}_{2} / \mathrm{EtOAC} 95 ; 5\right)$ : yield $73 \% ; \mathrm{mp}>260^{\circ} \mathrm{C} \mathrm{dec}\left(\mathrm{CH}_{2} \mathrm{Cl}_{2} / \mathrm{MeOH}\right)$ ${ }^{\prime} \mathrm{H}$ NMR $87.07,6.70(\mathrm{~s}, 4 \mathrm{H}, \mathrm{ArH}), 4.97\left(\mathrm{~s}, 4 \mathrm{H}, \mathrm{ArOCH}_{2}\right), 4.25$ and $3.33(\mathrm{ABq}, 8 \mathrm{H}, J=13.2 \mathrm{~Hz}, \mathrm{ArCH}, \mathrm{Ar}), 3.69,3.54\left(\mathrm{~s}, 6 \mathrm{H}, \mathrm{NCH}_{3}\right)$ $1.31,0.87\left[\mathrm{~s}, 18 \mathrm{H}, \mathrm{C}\left(\mathrm{CH}_{3}\right)_{3}\right] ;{ }^{13} \mathrm{C} \mathrm{NMR} \delta 195.6(\mathrm{~s}, \mathrm{C}-\mathrm{S}), 150.5,150.2$ (s, Ar 25,26,27,28-C), 147.4, 141.8 (s, Ar 5,11,17,23-C), 132.1, 127,8 (s, Ar 1,3,7,9,13,15,19,21-C), 125.6, 125.0 (d, all ArC-H), 81.5 (t $\left.\mathrm{OCH}_{2}\right), 44.6,42.5\left(\mathrm{q}, \mathrm{NCH}_{3}\right), 33.9\left[\mathrm{~s}, \mathrm{C}\left(\mathrm{CH}_{3}\right)_{3}\right], 31.8\left(\mathrm{t}, \mathrm{ArCH}_{2} \mathrm{Ar}\right)$, 31.7, $30.9[\mathrm{c}, \mathrm{C}(\mathrm{CH})$,$] ] FAB mass spectrum (NBA), m/e 851.4[(\mathrm{M}$ $+\mathrm{H})^{+}$, calcd 851.5]. Anal. Calcd for $\mathrm{C}_{52} \mathrm{H}_{70} \mathrm{~N}_{2} \mathrm{O}_{4} \mathrm{~S}_{2} \cdot 0.1 \mathrm{CH}_{2} \mathrm{Cl}_{2}: \mathrm{C}$, $72.95 ; \mathrm{H}, 8.01 ; \mathrm{N}, 3.27 ; \mathrm{S}, 7.48$. Found: $\mathrm{C}, 72.87 ; \mathrm{H}, 8.30 ; \mathrm{N}, 3.14 ; \mathrm{S}$, 7.62 ,

5,11,17,23-Tetrakis (1,1-dimethylethyl) -27,28-bis[(dimethylthiocarbamoyl)methoxy\}-25,26-dihydroxycalix[4]arene (21). Purification by column chromatography $\left(\mathrm{SiO}_{2}, \mathrm{CH}_{2} \mathrm{Cl}_{2}\right)$ : yield $90 \% ; \mathrm{mp} 246-248{ }^{\circ} \mathrm{C}$ $\left(\mathrm{CH}_{2} \mathrm{Cl}, \mathrm{MeOH}\right){ }^{\prime} \mathrm{H} \mathrm{NMR} \delta 9.34(\mathrm{~s}, 2 \mathrm{H}, \mathrm{OH}), 7.09$ (d, $2 \mathrm{H}, J=2.3$ $\mathrm{Hz}, \mathrm{ArH}), 7.06(\mathrm{~d}, 2 \mathrm{H}, J=2.2 \mathrm{~Hz}, \mathrm{ArH}), 6.98(\mathrm{~d}, 2 \mathrm{H}, J=2.3 \mathrm{~Hz}$, ArH), $6.93(\mathrm{~d}, 2 \mathrm{H}, J=2.3 \mathrm{~Hz}, \mathrm{ArH}), 5.17$ and $4.68(\mathrm{ABq}, 4 \mathrm{H}, J=$ $\left.12.5 \mathrm{~Hz}, \mathrm{ArOCH}_{2}\right), 4.73\left(\mathrm{~d}, 1 \mathrm{H}, J=12.4 \mathrm{~Hz}, \mathrm{ArCH}_{2} \mathrm{Ar} \mathrm{ax}\right), 4.55$ (d, $\left.2 \mathrm{H}, J=12.8 \mathrm{~Hz}_{1} \mathrm{ArCH}_{2} \mathrm{Ar} \mathrm{ax}\right), 4.26\left(\mathrm{~d}, 1 \mathrm{H}, J=13.6 \mathrm{~Hz}, \mathrm{ArCH}_{2} \mathrm{Ar}\right.$ ax), $3.61,3.52\left(\mathrm{~s}, 6 \mathrm{H}, \mathrm{NCH}_{3}\right), 3.47$ (d, I H, $J=12.8 \mathrm{~Hz}, \mathrm{ArCH}_{2} \mathrm{Ar}$ eq), $3.38\left(\mathrm{~d}, 1 \mathrm{H}, J=13.2 \mathrm{~Hz}, \mathrm{ArCH}{ }_{2} \mathrm{Ar} e q\right), 3.33(\mathrm{~d}, 2 \mathrm{H}, J=12.7$ $\left.\left.\mathrm{Hz}, \mathrm{ArCH}_{2} \mathrm{Ar} \mathrm{eq}\right), 1,22,1,15\left[\mathrm{~s}, 18 \mathrm{H}, \mathrm{C}\left(\mathrm{CH}_{3}\right)_{3}\right]\right)^{13} \mathrm{C} \mathrm{NMR} \delta 196.4(\mathrm{~s}$, $\mathrm{C}-\mathrm{S}$ ), 152.0, 149.4 (s, Ar 25,26,27,28-C), 147.0, 142.2 (s, At $5,11,17,23-\mathrm{C}), 134.1,132.6,128.3,127.2(\mathrm{~s}, \mathrm{Ar} 1,3,7,9,13,15,19,21-\mathrm{C})$ 126.5, 126.1, 125.7, 125.4 (d, all ArC-H), $80.9\left(1, \mathrm{ArOCH}_{2}\right), 44.4,42.3$ $\left(\mathrm{q}, \mathrm{NCH}_{3}\right), 34.1,33.9\left[\mathrm{~s}, \mathrm{C}\left(\mathrm{CH}_{3}\right)_{3}\right], 33.2\left(\mathrm{t}, \mathrm{ArCH}_{2} \mathrm{Ar}\right), 31.6,31.2[\mathrm{q}$, $\left.\mathrm{C}\left(\mathrm{CH}_{3}\right)_{3}\right] ; \mathrm{FAB}$ mass spectrum $(\mathrm{NBA}), \mathrm{m} / e 849.7\left[(\mathrm{M}+\mathrm{H})^{+}\right.$, calcd 849.5]. Anal. Caled for $\mathrm{C}_{52} \mathrm{H}_{70} \mathrm{~N}_{2} \mathrm{O}_{4} \mathrm{~S}_{2}: \mathrm{C}_{1}, 73.37 ; \mathrm{H}, 8.29 ; \mathrm{N}, 3.29 ; \mathrm{S}$, 7.53. Found: C, $72.97 ; \mathrm{H}, 8.39 ; \mathrm{N}, 3.10 ; \mathrm{S}, 7.42$.

27,28-Bis( (dimethylcarbamoyl)methoxy)-5,11,17,23-tetrakis(1,1-dlmethylethyl)-25,26-dibydroxycalix [4]arene (20). A suspension of $p$ tert-butylcalix[4]arene $1(2.50 \mathrm{~g}, 3.85 \mathrm{mmol})$ and sodium hydride $[0.49$ 8. $16.3 \mathrm{mmol}$; freed from mineral oll by washing with petroleum ether (bp $\left.\left.40-60^{\circ} \mathrm{C}\right)(2 \times 5 \mathrm{~mL})\right]$ in DMF $(50 \mathrm{~mL})$ was stirred at room temperature for $1 \mathrm{~h}$. Subsequently $N, N$-dimethyl-2-chloroacetamide $(1.03 \mathrm{~g}, 8.47 \mathrm{mmol})$ was added, and the reaction mixture was stirred overnight at $60^{\circ} \mathrm{C}$. The mixture was carefully acidified to $\mathrm{pH} 4$ with $2 \mathrm{~N} \mathrm{HCl}$, and the solvents were removed under reduced pressure. The residue was taken up in $\mathrm{CH}_{2} \mathrm{Cl}_{2}(200 \mathrm{~mL})$ and washed with saturated $\mathrm{NH}_{4} \mathrm{Cl}(4 \times 150 \mathrm{~mL})$. The organic layer was dried with $\mathrm{MgSO}_{4}$, and the solvent was removed under reduced pressure. The crude product was purified by column chromatography $\left(\mathrm{SiO}_{2}, \mathrm{CH}_{2} \mathrm{Cl}_{2} / \mathrm{BtOAc} 1: 3\right)$ to give 20 as a white powder $(1,31 \mathrm{~g}, 44 \%$ based upon recovered starting material): $\mathrm{mp} 245-247^{\circ} \mathrm{C}\left(\mathrm{CH}_{2} \mathrm{Cl}_{2} / \mathrm{MeOH}\right) ;{ }^{\prime} \mathrm{H}$ NMR $\delta 9.43$ (s, $2 \mathrm{H}$, $\mathrm{OH}), 6.92(\mathrm{~d}, 2 \mathrm{H}, J=2.3 \mathrm{~Hz}, \mathrm{ArH}), 6.87(\mathrm{~d}, 2 \mathrm{H}, J=2.3 \mathrm{~Hz}, \mathrm{ArH})$ $6.80(\mathrm{~s}, 4 \mathrm{H}, \mathrm{ArH}), 5.24$ and $4.67\left(\mathrm{ABq}, 4 \mathrm{H}, J=14.5 \mathrm{~Hz}, \mathrm{ArOCH}_{2}\right)$, 4.80 (d, $1 \mathrm{H}, J=13.3 \mathrm{~Hz}, \mathrm{ArCH}, \mathrm{Ar} \mathrm{ax}), 4.63(\mathrm{~d}, 2 \mathrm{H}, J=12.9 \mathrm{~Hz}$ $\left.\mathrm{ArCH}_{2} \mathrm{Ar} \mathrm{ax}\right), 4.34\left(\mathrm{~d}, 1 \mathrm{H}, J=13.7 \mathrm{~Hz}, \mathrm{ArCH}_{2} \mathrm{Ar} \mathrm{ax}\right), 3.34(\mathrm{~d}, 1 \mathrm{H}$, $\left.J=13.5 \mathrm{~Hz}, \mathrm{ArCH}_{2} \mathrm{Ar} \mathrm{eq}\right), 3.25\left(\mathrm{~d}, 3 \mathrm{H}, J=12.9 \mathrm{~Hz}, \mathrm{ArCH}_{2} \mathrm{Ar} \mathrm{eq}\right.$ ) $3.09,3.03\left(\mathrm{~s}, 6 \mathrm{H}, \mathrm{NCH}_{3}\right), 1.17,1.02\left[\mathrm{~s}, 18 \mathrm{H}, \mathrm{C}\left(\mathrm{CH}_{3}\right)_{3}\right]{ }^{13} \mathrm{C} \mathrm{NMR}$ $170.0(s, C=0), 154,0,149,1(s$, Ar 25,26,27,28-C), 146.0, $141.2(s$, Ar $5,11,17,23-\mathrm{C}), 134.0,132,8,127,5,127,2$ (s, Ar 1,3,7,9,13,15,19,21-C) 125.9, 125.6, 125.0, 124.9 (d, all ArC-H), $73.4\left(t, \mathrm{ArOCH}_{2}\right), 36.1,35.7$ $\left(\mathrm{q}, \mathrm{NCH}_{3}\right), 33,9,33.7\left[\mathrm{~s}, \mathrm{C}\left(\mathrm{CH}_{3}\right)_{3}\right], 32.0\left(\mathrm{t}, \mathrm{ArCH}_{2} \mathrm{Ar}\right), 31.5,31.2[\mathrm{q}$ $\left.\mathrm{C}\left(\mathrm{CH}_{3}\right)_{3}\right] ; \mathrm{FAB}$ mass spectrum $(\mathrm{NBA}), m / e 819.5^{2}\left[(\mathrm{M}+\mathrm{H})^{+}\right.$, caled 8 19.5]. Anal, Calcd for $\mathrm{C}_{52} \mathrm{H}_{70} \mathrm{~N}_{2} \mathrm{O}_{6} \cdot 0.05 \mathrm{CH}_{2} \mathrm{Cl}_{2}: \mathrm{C}, 75.93 ; \mathrm{H}, 8.58$; $\mathrm{N}, 3.40$. Found: $\mathrm{C}, 75.75 ; \mathrm{H}, 8.58 ; \mathrm{N}, 3.21$.

Alkylation of Tetrakds (2-hydroxyetboxy)-p-tert-butylcallix (4)arene 11 and Bls (2-bydroxyethoxy)-p-tert-butylcalix[4]arene 15 with $N, N$-Dimethyl-2-chloroacetamide. Formation of 22 and 24. A suspension of (2-hydroxyethoxy)-p-tert-butylcalix [4]arenes 11 and $15(3.0 \mathrm{mmol})$ and sodium hydride $[0.90 \mathrm{~g}, 30.0 \mathrm{mmol}$ in the case of $11,0.45 \mathrm{~g}, 15.0 \mathrm{mmol}$ in the case of 15; freed from mineral oil by washing with petroleum ether (bp $\left.\left.40-60^{\circ} \mathrm{C}\right)(2 \times 10 \mathrm{~mL})\right]$ in DMF $(150 \mathrm{~mL})$ was stirred at room temperature for $1 \mathrm{~h}$. Subsequently $N, N$-dimethyl-2-chloroacetamide (3.65 g, $30.0 \mathrm{mmol}$ in the case of $11,1.82 \mathrm{~g}, 15.0 \mathrm{mmol}$ in the case of 15) was added, and the mixture was stirred overnight at $60^{\circ} \mathrm{C}$. The mixture was acidified carefully to $\mathrm{pH} 4$ with $2 \mathrm{~N} \mathrm{HCl}$, and the solvents were removed under reduced pressure. The residue was taken up in $\mathrm{CH}_{2} \mathrm{Cl}_{2}(200 \mathrm{~mL})$ and washed with $2 \mathrm{~N} \mathrm{HCl}(200 \mathrm{~mL})$, followed by washing with saturated $\mathrm{NH}_{4} \mathrm{Cl}(4 \times 200 \mathrm{~mL})$ and doubly distilled water $(200 \mathrm{~mL})$. The organic layer was dried over $\mathrm{MgSO}_{4}$, and the solvent was removed under reduced pressure to give an oil, which was solidified with petroleum ether (bp 40-60 ${ }^{\circ} \mathrm{C}$ ).

25,26,27,28-Tetrakis[((dimethylcarbamoyl) methoxy)ethoxy]$5,11,17,23-$ tetrakis (1,1-dimethylethyl) calix [4]arene (22): yield 86\%; mp $171-173^{\circ} \mathrm{C}\left[\mathrm{CH}_{2} \mathrm{Cl}_{2} /\right.$ petroleum ether (bp $\left.\left.40-60^{\circ} \mathrm{C}\right)\right]$; ${ }^{\mathrm{H}} \mathrm{NMR} \delta 6.76$ $(\mathrm{s}, 8 \mathrm{H}, \mathrm{ArH}), 4.41$ and $3.12\left(\mathrm{ABq}, 8 \mathrm{H}, J=12.6 \mathrm{~Hz}, \mathrm{ArCH}_{2} \mathrm{Ar}\right), 4.26$ $\left(\mathrm{s}, 8 \mathrm{H}, \mathrm{OCH}_{2} \mathrm{C}=0\right), 4.2-4.1\left(\mathrm{~m}, 8 \mathrm{H}, \mathrm{ArOCH} \mathrm{CH}_{2}\right), 4.1-4.0(\mathrm{~m}, 8 \mathrm{H}$, $\left.\mathrm{ArOCH}_{2} \mathrm{CH}_{2} \mathrm{O}\right), 2.99,2.93\left(\mathrm{~s}, 12 \mathrm{H}, \mathrm{NCH}_{3}\right), 1.07\left[\mathrm{~s}, 36 \mathrm{H}, \mathrm{C}\left(\mathrm{CH}_{3}\right)_{3}\right]$; ${ }^{13} \mathrm{C}$ NMR $\delta 169.4(\mathrm{~s}, \mathrm{C}=0), 153.2(\mathrm{~s}, \mathrm{Ar} 25,26,27,28-\mathrm{C}), 144.7(\mathrm{~s}, \mathrm{Ar}$ $5,11,17,23-\mathrm{C}), 133,7(\mathrm{~s}, \mathrm{Ar} 1,3,7,9,13,15,19,21-\mathrm{C}), 125.0$ (d, all ArC-H), 72.8, 70.7, $70.1\left(\mathrm{t}\right.$, all $\left.\mathrm{OCH}_{2}\right), 36.3,35.3\left(\mathrm{q}, \mathrm{NCH}_{3}\right), 33.8\left[\mathrm{~s}, \mathrm{C}\left(\mathrm{CH}_{3}\right)_{3}\right]$, $31.4\left[\mathrm{q}, \mathrm{C}\left(\mathrm{CH}_{3}\right)\right], 31.1(\mathrm{t}, \mathrm{ArCH}, \mathrm{Ar}) ; \mathrm{FAB}$ mass spectrum (NBA), $m / \mathrm{e}$ $1165.7\left[(\mathrm{M}+\mathrm{H})^{+}\right.$, calcd 1165.7]. Anal. Calcd for $\mathrm{C}_{68} \mathrm{H}_{100} \mathrm{~N}_{4} \mathrm{O}_{12}$ $0.3 \mathrm{CH}_{2} \mathrm{Cl}_{2}: \mathrm{C}, 68.88 ; \mathrm{H}, 8.51 ; \mathrm{N}, 4.70$. Found: $\mathrm{C}, 68.56 ; \mathrm{H}, 8.67 ; \mathrm{N}$, 4.59.

23,27-Bis[((dimethylcarbamoyl)methoxy)ethoxy-5,11,17,23-tetrakin(1,1-dimethylethyl)-26,28-dipropoxycalix [4\}arene (24): yield 60\%; mp $>220^{\circ} \mathrm{C}$ dec $\left(\mathrm{CH}_{2} \mathrm{Cl}{ }_{2} / \mathrm{MeOH}\right)$; ' $\mathrm{H}$ NMR $86.86,6.67(\mathrm{~s}, 4 \mathrm{H}, \mathrm{ArH})$, 4.38 and $3.11\left(\mathrm{ABq}, 8 \mathrm{H}, J=12.5 \mathrm{~Hz}, \mathrm{ArCH}_{2} \mathrm{Ar}\right), 4.20(\mathrm{~s}, 4 \mathrm{H}$, $\left.\mathrm{CH}_{2} \mathrm{C}=\mathrm{O}\right), 4.18\left(\mathrm{t}, 4 \mathrm{H}, J=5.9 \mathrm{~Hz}, \mathrm{ArOCH}_{2} \mathrm{CH}_{2} \mathrm{O}\right), 4.06(\mathrm{t}, 4 \mathrm{H}, J$ $\left.=5.9 \mathrm{~Hz}, \mathrm{ArOCH} 2 \mathrm{CH}_{2} \mathrm{O}\right), 3.78\left(1,4 \mathrm{H}, J=7.7 \mathrm{~Hz}, \mathrm{ArOCH}_{2} \mathrm{CH}_{2} \mathrm{CH}_{3}\right)$, $3.00,2.95\left(\mathrm{~s}, 6 \mathrm{H}, \mathrm{NCH}_{3}\right), 2.1-1.9\left(\mathrm{~m}, 4 \mathrm{H}, \mathrm{ArOCH}_{2} \mathrm{CH}_{2} \mathrm{CH}_{3}\right), 1.15$, $0.99\left[\mathrm{~s}, 18 \mathrm{H}, \mathrm{C}\left(\mathrm{CH}_{3}\right)_{3}\right], 0.99\left(\mathfrak{t}, 6 \mathrm{H}, J=7.4 \mathrm{~Hz}_{3} \mathrm{ArOCH}_{2} \mathrm{CH}_{2} \mathrm{CH}_{3}\right)$; ${ }^{13} \mathrm{C}$ NMR $\delta 169.2(\mathrm{~s}, \mathrm{C}=0$ ) $153.5,153.3$ (s, Ar 25,26,27,28-C), 144.7, 144.2 (s, Ar 5,11,17,23-C), 134.3, 133.1 (s, Ar 1,3,7,9,13,15,19,21-C) 125.1, 124.8 (d, all ArC-H), 77.2 (t, ArOCH $\left.\mathrm{CH}_{2} \mathrm{CH}_{3}\right), 72.3,70.6$ (t, ArOCH $\mathrm{CH}_{2} \mathrm{O}$, ArOCH $\mathrm{CH}_{2} \mathrm{O}$, and $\left.\mathrm{CH}_{2} \mathrm{C}=0\right)$, 36.4, 35.5 $\left(\mathrm{q}, \mathrm{NCH}_{3}\right)$, 33.9, 33.7 [s, $\left.\mathrm{C}\left(\mathrm{CH}_{3}\right)_{3}\right], 31.5,31.3$ [q, $\left.\mathrm{C}\left(\mathrm{CH}_{3}\right)_{3}\right], 31.1\left(\mathrm{t}, \mathrm{ArCH}_{2} \mathrm{Ar}\right)$, 23.3 (t, ArOCH $\mathrm{CH}_{2} \mathrm{CH}_{3}$ ), 10.5 (q, ArOCH $\mathrm{CH}_{2} \mathrm{CH}_{3}$ ); FAB mass spectrum (NBA), $\mathrm{m} / \mathrm{e} 991.5\left[(\mathrm{M}+\mathrm{H})^{+}\right.$, calcd 991.7$]$. Anal, Caled for $\mathrm{C}_{62} \mathrm{H}_{90} \mathrm{~N}_{2} \mathrm{O}_{8}: \mathrm{C}, 75.11 ; \mathrm{H}, 9.15 ; \mathrm{N}, 2.83$. Found: $\mathrm{C}, 74.78 ; \mathrm{H}, 9.11 ; \mathrm{N}$, 2.63 .

$5,11,17,23-T e t r a k i s(1,1$-dimethylethyl)-25,26,27,28-tetrakis[((d)methylthiocarbamoyl)methoxy)ethoxy\}calix (4)arene (23). A mixture of tetraamide calix [4] arene $22(1.00 \mathrm{~g}, 0.89 \mathrm{mmol})$ and Lawesson's reagent $(0.80 \mathrm{~g}, 1.98 \mathrm{mmol})$ in toluene $(25 \mathrm{~mL})$ was stirred overnight at $90^{\circ} \mathrm{C}$. The solvent was removed under reduced pressure, and purification by column chromatography $\left(\mathrm{SiO}_{2}, \mathrm{EtOAc} / \mathrm{CH}_{2} \mathrm{Cl}_{2} 3: 1\right)$ afforded 23 as an off-white powder $\left(0.51 \mathrm{~g}_{1} 48 \%\right)$; mp $126-128^{\circ} \mathrm{C}\left(\mathrm{CH}_{2} \mathrm{Cl}_{2} / \mathrm{MeOH}\right)$; ' $\mathrm{H}$ NMR $86.76(\mathrm{~s}, 8 \mathrm{H}, \mathrm{ArH}), 4.61\left(\mathrm{~s}, 8 \mathrm{H}, \mathrm{OCH}_{2} \mathrm{C}-\mathrm{S}\right), 4.39$ and 3.11 $\left(\mathrm{ABq}, 8 \mathrm{H}, J=12.6 \mathrm{~Hz}, \mathrm{ArCH} \mathrm{Ar}^{2}, 4.2-4.1\left(\mathrm{~m}, 8 \mathrm{H}, \mathrm{ArOCH}_{2}\right), 4.1-4.0\right.$ $(\mathrm{m}, 8 \mathrm{H}, \mathrm{ArOCH}, \mathrm{CH}), 3.43,3.36\left(\mathrm{~s}, 12 \mathrm{H}, \mathrm{NCH}_{3}\right), 1.07[\mathrm{~s}, 36 \mathrm{H}$, $\left.\mathrm{C}\left(\mathrm{CH}_{3}\right)_{3}\right] ;{ }^{13} \mathrm{C} N M R \delta 197.6(\mathrm{~s}, \mathrm{C}=\mathrm{S}), 153.2(\mathrm{~s}, \mathrm{Ar} 25,26,27,28-\mathrm{C})$, 144.7 (s, Ar 5,11,17,23-C), 133.6 (s, Ar-1,3,7,9,13,15,19,21-C), 125,0 (d, all ArC-H), 78.4 $\left(t, \mathrm{ArOCH}_{2}\right), 72.9,70.3\left(\mathrm{t}, \mathrm{ArOCH}_{2} \mathrm{CH}_{2}\right.$ and $\left.\mathrm{OCH}_{2} \mathrm{C}=\mathrm{S}\right), 44.5,42.2\left(\mathrm{q}, \mathrm{NCH}_{3}\right), 33.8\left[\mathrm{~s}, \mathrm{C}\left(\mathrm{CH}_{3}\right)\right], 31.4$ la, C$\left.\left(\mathrm{CH}_{3}\right)_{3}\right], 31.2\left(\mathrm{t}, \mathrm{ArCH} \mathrm{H}_{2} \mathrm{Ar}\right) ; \mathrm{FAB}$ mass spectrum (NBA), m/e 1228.6 $\left(\mathrm{M}^{+}\right.$, calcd 1228.6). Anal. Calcd for $\mathrm{C}_{68} \mathrm{H}_{100} \mathrm{~N}_{4} \mathrm{O}_{8} \mathrm{~S}_{4} \cdot 0.1 \mathrm{CH}_{2} \mathrm{Cl}_{2}: \mathrm{C}$, $66.05 ; \mathrm{H}, 8.16 ; \mathrm{N}, 4.52 ; \mathrm{S}, 10.35$. Found: $\mathrm{C}, 66.12 ; \mathrm{H}, 8.32 ; \mathrm{N}, 4.20 ;$ $S, 9.95$.

5,11,17,23-Tetrakis(1,1-dimethylethyl)-25,27-bis[((dimethylthio carbamoyl)methoxy)ethoxy\}-26,28-dipropoxycallix (4)arene (23). A mixture of p-tert-butylcalix [4]arene $24(1.00 \mathrm{~g}, 1.01 \mathrm{mmol})$ and Lawesson's reagent $(0.45 \mathrm{~g}, 1.11 \mathrm{mmol})$ in toluene $(20 \mathrm{~mL})$ was heated overnight at $85^{\circ} \mathrm{C}$. Evaporation of the solvent, followed by column chromatography $\left(\mathrm{SiO}_{2}\right.$, first $\mathrm{CH}_{2} \mathrm{Cl}_{2}$ to remove traces of Lawesson's material, then $\left.\mathrm{CH}_{2} \mathrm{Cl}_{2} / \mathrm{EtOAc} 1: 9\right)$ gave an oil which was crystallized from water to give $25^{\prime}(0.90 \mathrm{~g}, 87 \%)$ : $\mathrm{mp} 166-167^{\circ} \mathrm{C}$; ${ }^{\mathrm{H}} \mathrm{H}$ NMR $\delta 6,92,6.60(8,4 \mathrm{H}$ $\operatorname{ArH}), 4.59(\mathrm{~s}, 4 \mathrm{H}, \mathrm{CH}, \mathrm{C}=\mathrm{S}), 4.37$ and $3.11(\mathrm{ABq}, 8 \mathrm{H}, J=12.6 \mathrm{~Hz}$ $\left.\mathrm{ArCH}_{2} \mathrm{Ar}\right), 4.25-4.1\left(\mathrm{~m}, 8 \mathrm{H}, \mathrm{ArOCH} \mathrm{CH}_{2} \mathrm{O}\right.$ and $\mathrm{ArOCCH} \mathrm{CH}_{2} \mathrm{O}$ ) 3.75 $\left(\mathrm{t}, 4 \mathrm{H}, J=7.6 \mathrm{~Hz}\right.$, ArOCH $\left.\mathrm{CH}_{2} \mathrm{CH}_{3}\right), 3.43,3.32\left(\mathrm{~s}, 6 \mathrm{H}, \mathrm{NCH}_{3}\right)$ 2.1-1.9 (m, $\left.4 \mathrm{H}, \mathrm{ArOCH} \mathrm{CH}_{2} \mathrm{CH}_{3}\right), 1.19,0.94\left[\mathrm{~s}, 18 \mathrm{H}, \mathrm{C}\left(\mathrm{CH}_{3}\right)_{3}\right], 1.01$ $\left(i, 6 \mathrm{H}, J=7.4 \mathrm{~Hz}, \mathrm{ArOCH}_{2} \mathrm{CH}_{2} \mathrm{CH}_{3}\right) ;{ }^{13} \mathrm{C}$ NMR $\delta 197.7(\mathrm{~s}, \mathrm{C}-\mathrm{S})$ $153.8,153.1$ ( $\mathrm{s}, \mathrm{Ar} 25,26,27,28-\mathrm{C}), 144.8,144.2$ (s, Ar 5,11,17,23.C), 134.6, 132.7 (s, Ar, 1,3,7,9,13,15,19,21-C), 125.2, 124.7 (d, all ArC-H) 78.7 $\left(t, \mathrm{ArOCH}_{2} \mathrm{CH}_{2} \mathrm{CH}_{3}\right), 72.4,70.5\left(t_{1}, \mathrm{ArOCH}_{2} \mathrm{CH}_{2} \mathrm{O}, \mathrm{ArOCH}{ }_{2} \mathrm{C}\right.$. $\mathrm{H}_{2} \mathrm{O}$, and $\left.\mathrm{CH}_{2} \mathrm{C}=\mathrm{S}\right), 44.5,42.0\left(\mathrm{q}, \mathrm{NCH}_{3}\right), 33.9,33.7\left[\mathrm{~s}, \mathrm{C}\left(\mathrm{CH}_{3}\right)_{3}\right]$, $31.6,31.3\left[\mathrm{q}, \mathrm{C}\left(\mathrm{CH}_{3}\right)_{3}\right], 31.2\left(\mathrm{t}, \mathrm{ArCH} \mathrm{Arr}_{2}\right), 23.5\left(\mathrm{t}, \mathrm{ArOCH}_{2} \mathrm{CH}_{2} \mathrm{CH}_{3}\right)$ $10.6\left(q, \mathrm{ArOCH}_{2} \mathrm{CH}_{2} \mathrm{CH}_{3}\right)$; FAB mass spectrum (NBA), $m / e$ 1023.5 $\left[(\mathrm{M}+\mathrm{H})^{+}\right.$, caled 1023.6]. Anal. Caled for $\mathrm{C}_{62} \mathrm{H}_{90} \mathrm{~N}_{2} \mathrm{O}_{6} \mathrm{~S}_{2} \cdot 0.33 \mathrm{H}_{2} \mathrm{O}$ : 
C, $72.34 ; H, 8.88 ; N, 2.72 ; S, 6.23$. Found: $C, 72.23 ; H, 8.97 ; N, 2.44 ;$ $S, 6.01$. Karl Fisher titration calcd for $0.33 \mathrm{H}_{2} \mathrm{O}: 0.58$. Found; 0.57 . 25,27-B|\&[(dimethylcarbamoyl)methoxy] $5,11,17,23$-tetrakls(1,1-dimethylethyl)-26,28-dipropoxycalix[4]arene (26). A suspension of 25,27 . dihydroxy-26,28-dipropoxy-p-tert-butylcalix[4] arene $4(6.70 \mathrm{~g}, 9.14$ mmol) and sodium hydride $[1.34 \mathrm{~g}, 44.7 \mathrm{mmol}$; freed from mineral oil by washing with petroleum ether (bp $\left.\left.40-60^{\circ} \mathrm{C}\right)(2 \times 10 \mathrm{~mL})\right]$ in a mixture of DMF $(60 \mathrm{~mL})$ and THF $(300 \mathrm{~mL})$ was stirred at room temperature for $1 \mathrm{~h}$. Subsequently $N, N$-dimethyl-2-chloroacetamide $(4.42 \mathrm{~g}, 36.4 \mathrm{mmol})$ was added, and the mixture was stired overnight at 55-60 ${ }^{\circ} \mathrm{C}$. After removal of the solvents under reduced pressure the residue was dissolved in $\mathrm{CH}_{2} \mathrm{Cl}_{2}(250 \mathrm{~mL})$ and washed with saturated $\mathrm{NH}_{4} \mathrm{Cl}$ solution $(4 \times 200 \mathrm{~mL})$, followed by brine $(1 \times 100 \mathrm{~mL})$. The organic layer was dried with $\mathrm{MgSO}_{4}$ and the solvent was evaporated. The crudo product was crystallized from disopropyl ether to give 26 as a white powder $(4.60 \mathrm{~g}, 56 \%) ; \mathrm{mp} 225-229^{\circ} \mathrm{C}\left(\mathrm{CH}_{2} \mathrm{Cl}_{2} / \mathrm{MeOH}\right){ }^{\prime} \mathrm{H}$ NMR $\delta 6.93,6.61(\mathrm{~s}, 4 \mathrm{H}, \mathrm{ArH}), 4.60\left[\mathrm{~s}, 4 \mathrm{H}, \mathrm{OCH} \mathrm{C}(\mathrm{O}) \mathrm{N}\left(\mathrm{CH}_{3}\right)_{2}\right]$ 4.53 and $3.17\left(\mathrm{ABq}, 8 \mathrm{H}, J=12.7 \mathrm{~Hz}, \mathrm{ArCH}_{2} \mathrm{Ar}\right), 3.92(\mathrm{t}, 4 \mathrm{H}, J=8.0$ $\left.\mathrm{Hz}, \mathrm{OCH}, \mathrm{CH}_{2}\right), 3.09,2.99\left(\mathrm{~s}, 6 \mathrm{H}, \mathrm{NCH}_{3}\right), 2.1-1.95(\mathrm{~m}, 4 \mathrm{H}$ $\left.\mathrm{OCH}_{2} \mathrm{CH}_{2}\right), 1.19,0.95\left[\mathrm{~s}, 18 \mathrm{H}, \mathrm{C}\left(\mathrm{CH}_{3}\right)_{3}\right] ;{ }^{13} \mathrm{C}$ NMR $\delta 168.9(\mathrm{~s}, \mathrm{C}=0)$ $154.2,152.9$ (s, Ar 25,26,27,28-C), 144.7, 144.5 (s, Ar 5,11,17,23-C), $134.5,132.6(\mathrm{~s}$, Ar $1,3,7,9,13,15,19,21-\mathrm{C}), 125.3,125.0$ (d, all ArC-H) $76.7\left(\mathrm{t}, \mathrm{ArOCH} \mathrm{CH}_{2}\right), 72.8\left[\mathrm{t}, \mathrm{ArOCH}_{2} \mathrm{C}(\mathrm{O}) \mathrm{N}(\mathrm{Me})_{2}\right], 37.1,35.4(\mathrm{q}$ $\mathrm{NCH})_{3}, 33.9,33.7\left[\mathrm{~s}, \mathrm{C}\left(\mathrm{CH}_{3}\right)_{3}\right], 31.6,31.3\left(\mathrm{q}, \mathrm{C}\left(\mathrm{CH}_{3}\right)_{3}\right], 31.4(\mathrm{t}$, $\left.\mathrm{ArCH}_{2} \mathrm{Ar}\right), 23.2\left(\mathrm{t}, \mathrm{ArOCH} \mathrm{CH}_{2}\right), 10.3\left(\mathrm{q}, \mathrm{OCH}_{2} \mathrm{CH}_{2} \mathrm{CH}_{3}\right) ; \mathrm{FAB}$ mass spectrum (NBA), $m / e 903.8\left[(\mathrm{M}+\mathrm{H})^{+}\right.$, calcd 903.6]. Anal. Calod for $\mathrm{C}_{58} \mathrm{H}_{82} \mathrm{~N}_{2} \mathrm{O}_{6} \cdot 0.3 \mathrm{CH}_{2} \mathrm{Cl}_{2} ; \mathrm{C}, 75.39 ; \mathrm{H}, 8.96 ; \mathrm{N}, 3.02$. Found: $\mathrm{C}, 75.51$; $\mathrm{H}, 9.16 ; \mathrm{N}, 2.93$

5,11,17,23-Tetrakis (1,1-dimethylethyl)-25,27-bis[(dimethyltbio carbamoyl)metboxy]-26,28-dipropoxycalix[4]arene (27) was synthesized starting from $26(4.10 \mathrm{~g}, 4.54 \mathrm{mmol})$ in analogy with the procedure given for the preparation of 25. The residue was crystallized from $\mathrm{MeOH}$ and further purified by column chromatography $\left(\mathrm{SiO}_{2} / \mathrm{CH}_{2} \mathrm{Cl}\right.$, to remove traces of Lawessons material; later the eluent was changed to $\mathrm{CH}_{2} \mathrm{Cl}_{2} /$ EtOAc $\left.1: 1\right)$ to yield 27 as a light-yellow powder $(3.48 \mathrm{~g}, 82 \%)$ : mp 276-278 ${ }^{\circ} \mathrm{C}(\mathrm{MeOH})$; 'H NMR $87.19(\mathrm{~s}, 4 \mathrm{H}, \mathrm{ArH}), 6.45(\mathrm{~s}, 4 \mathrm{H}$ ArH) $4.77\left[\mathrm{~s}, 4 \mathrm{H}, \mathrm{C}(\mathrm{S}) \mathrm{CH}_{2}\right], 4.48$ and $3.17(\mathrm{ABq}, 8 \mathrm{H}, J=12.6 \mathrm{~Hz}$, $\left.\mathrm{ArCH}_{2} \mathrm{Ar}\right), 3.93\left(1,4 \mathrm{H}, J=8.4 \mathrm{~Hz}, \mathrm{OCH}_{2} \mathrm{CH}\right), 3.51\left(\mathrm{~s}, 12 \mathrm{H}, \mathrm{NCH}_{3}\right)$ $2.1-1.95\left(\mathrm{~m}, 4 \mathrm{H}, \mathrm{OCH}_{2} \mathrm{CH}_{2}\right), 1.32,0.82\left[\mathrm{~s}, 18 \mathrm{H}_{1} \mathrm{C}\left(\mathrm{CH}_{3}\right)_{3}\right], 0.89(\mathrm{t}$, $\left.6 \mathrm{H}, \mathrm{CH}_{2} \mathrm{CH}_{3}\right) ;{ }^{13} \mathrm{C} \mathrm{NMR} \mathrm{\delta} 196.6(\mathrm{~s}, \mathrm{C}-\mathrm{S}), 154.1,151.8(\mathrm{~s}, \mathrm{Ar}$ $25,26,27,28-\mathrm{C}$ ), 144.6 (s, Ar 5,11,17,23-C), 135.1, 131.5 (s, Ar $1,3,7,9,13,15,19,21-\mathrm{C}), 125.4,124.5$ (d, all ArC-H), $81,0\left[\mathrm{t}, \mathrm{C}(\mathrm{S}) \mathrm{CH}_{2}\right]$, $76.3\left(\mathrm{t}, \mathrm{OCH}_{2} \mathrm{CH}_{2}\right), 44.1,42.0\left(\mathrm{q}, \mathrm{NCH}_{3}\right), 33.9,33.4\left[\mathrm{~s}, \mathrm{C}\left(\mathrm{CH}_{3}\right)_{3}\right], 31.5$ $30.9\left[\mathrm{q}, \mathrm{C}\left(\mathrm{CH}_{3}\right)_{3}\right], 31.0\left(\mathrm{t}, \mathrm{ArCH} \mathrm{Ar}_{2}\right), 23.1\left(\mathrm{t}, \mathrm{OCH}_{2} \mathrm{CH}_{2}\right), 9.8(\mathrm{q}$ $\mathrm{CH}_{2} \mathrm{CH}_{3}$ ); FAB mass spectrum (PEG), $m / e$ 935.5 (M+ ${ }^{+}$, calcd 935.6) Anal. Calcd for $\mathrm{C}_{38} \mathrm{H}_{82} \mathrm{~N}_{2} \mathrm{O}_{4} \mathrm{~S}_{2} ; \mathrm{C}_{1} 74.47 ; \mathrm{H}, 8.84 ; \mathrm{N}, 2.99 ; \mathrm{S}, 6.86$. Found: $\mathrm{C}, 74.59 ; \mathrm{H}, 9.08 ; \mathrm{N}, 2.87 ; \mathrm{S}, 6.74$.

$5,11,17,23$-Tetrakis (1,1-dimethylethyl)-25,26,27,28-tetrakls[(dimethylthlocarbamoyl)methoxy]callx[4]arene (29) was synthesized starting from $28(6.0 \mathrm{~g}, 6.06 \mathrm{mmol})$ in analogy with the procedure given for the preparation of 23. The mixture was crystallized from $\mathrm{MeOH}$ and purified by column chromatography $\left(\mathrm{SiO}_{2}, \mathrm{CH}_{2} \mathrm{Cl}_{2} / \mathrm{EtOAc} 8: 2\right)$ to yield 29 as an off-white powder $(5.33 \mathrm{~g}, 83 \%)$ : $\mathrm{mp} 268-272^{\circ} \mathrm{C}$ dec $\left(\mathrm{CH}_{2} \mathrm{Cl}_{2} / \mathrm{MeOH}\right)$; $\mathrm{H}$ NMR $86.80(\mathrm{~s}, 8 \mathrm{H}, \mathrm{ArH}), 5.04$ (s, $8 \mathrm{H}$, Ar$\mathrm{OCH}_{2}, 4.69$ and $3.14\left(\mathrm{ABq}, 8 \mathrm{H}, J=12.8 \mathrm{~Hz}_{1} \mathrm{ArCH}, \mathrm{Ar}\right), 3.48,3.28$ $\left(\mathrm{s}, 12 \mathrm{H}, \mathrm{NCH}_{3}\right), 1.07\left[\mathrm{~s}, 36 \mathrm{H}, \mathrm{C}\left(\mathrm{CH}_{3}\right)_{3}\right] ;{ }^{13} \mathrm{C} \mathrm{NMR} \delta 197.5$ (s, C-S), $152.8(s, \operatorname{Ar} 25,26,27,28-C), 142.2(s, \operatorname{Ar} 5,11,17,23-\mathrm{C}), 133.3$ (s, Ar $1,3,7,9,13,15,19,21-\mathrm{C}), 125.4$ (d, all ArC-H), 80.1 (t, ArOCH${ }_{2}$ ), 44.7, $42.6\left(\mathrm{q}, \mathrm{NCH}_{3}\right), 33.9\left[\mathrm{~s}, \mathrm{C}\left(\mathrm{CH}_{3}\right)_{3}\right], 31.4\left[\mathrm{q}, \mathrm{C}\left(\mathrm{CH}_{3}\right)_{3}\right], 31.3(\mathrm{l}$,
A.rCH, Ar); FAB mass spectrum (NBA), $m / e$ 1054.1 $\left[(\mathrm{M}+\mathrm{H})^{+}\right.$, caled 1053.5]. Anal. Calcd for $\mathrm{C}_{36} \mathrm{H}_{76} \mathrm{~N}_{4} \mathrm{O} \mathrm{S}_{4}: \mathrm{C}, 68.40 ; \mathrm{H}, 8.04 ; \mathrm{N}, 5.32$. $S, 12.17$. Found: $C, 68.33 ; H, 8.03 ; \mathrm{N}, 5.22 ; \mathrm{S}, 12.10$.

CHEMFETs, Chemicals. Commercial (3-methacryloxypropyl)trimethoxysilane (MEMO) (Janssen Chimica), ethyleneglycol dimethacrylate (EGDMA, Merck-Schuchardt), and 2-hydroxyethyl methacrylate (HEMA, Merck-Schuchardt) were used. Poly(vinylpyrrolidone) (PVP) with an average molecular weight of 360.000 Dalton (Janssen Chimica) was used. Potassium tetrakis(4-chlorophenyl)borate (KTCPB) bis(2-ethylhexyl)sebacate (DOS), bis(2-ethylhexyl)phthalate (DOP), and o-nitrophenyl octyl ether (o-NPOE) were obtained from Fluka. Tetrahydrofuran (THF) was freshly distilled from benzophenone/sodium before use. Cadmium chloride was obtained from Janssen Chimica. Lead chloride was purchased from BDH Chemicals Ltd. All other chloride or nitrate salts or acids used were of analytical-reagent grade (MerckSchuchardt), and solutions were prepared with doubly distilled, deionized, $\mathrm{CO}_{2}$-free water.

CHEMFET. The ISFETs were fabricated as described previously, but the detailed structure of the ISFET has been changed compared to the previous design. The external dimensions were enlarged from $1.2 \times$ 3.0 to $3.0 \times 5.0 \mathrm{~mm}$, and the number of contact pads were reduced from three to two by connecting the source and the bulk internally. The size of the contact pads are $1.0 \times 1.25 \mathrm{~mm}$. Surface silylation of a wafer with MEMO was performed as described before." A hydrogel was applied on wafer scale on the gate oxide of the ISFET by photopolymerization with a mask aligner of a mixture of EGDMA, HEMA, PVP, water, and photoinitiator in a $w / w$ ratio of $0.4: 100: 10: 40: 4$, respectively. The resulting poly HEMA layer had dimensions of $800 \mu \mathrm{m} \times 800 \mu \mathrm{m} \times 15 \mu \mathrm{m}$ The encapsulated sensors were prepared by mounting the ISFET on a printed circuit board. After wire bonding and encapsulation with an epoxy resin (Hysol H-W796/C8 W795) the sensor was soaked in a solution of $10 \mathrm{mM}$ primary ion and $0.1 \mathrm{mM}$ acid for $1 \mathrm{~h}$. The ion-sensitive membranes were prepared in a glass tube by dissolving a $10 \%$ mixture of ionophore, KTCPB, plasticizer, and PVC in THF. Fifteen microliters of this solution was applied to the encapsulated ISFETs. These solutions were only used once. The response of the CHEMFET was measured with a source and drain follower type ISFET amplifier in a constant drain-current mode $\left(I_{\mathrm{d}}=100 \mu \mathrm{A}\right)$, with a constant drainsource potential $\left(V_{\mathrm{dt}}=0.5 \mathrm{~V}\right)$, The reference electrode was a calomel clectrode. The signal of the ISFET amplifier was recorded with an Apple Ile computer.

Measurements. The experimental setup to measure the encapsulated sensors was described before ${ }^{41}$ and used without modification. The en capsulated sensors were, after evaporation of the solvent, conditioned overnight in a solution of $10 \mathrm{mM}$ primary ion and $0.1 \mathrm{mM}$ acid. The selectivity coefficients were determined by the fixed interference method (FIM) ${ }^{6.7}$ All solutions were prepared freshly and adjusted to $\mathrm{pH} 4$ (hydrochloric or nitric acid). The activity of the primary ion in solution was increased in steps of 0.1 ( $\log$ a for silver, cadmium, or lead) or 0.2 ( $\log a$ for copper). After addition the solution was stirred in order to obtain a homogeneous solution. The waiting time between stirring and data acquisition was elther $0.5 \mathrm{~min}$ (silver, cadmium, or lead) or $1 \mathrm{~min}$ (copper). Corrections for the activity of the salts were calculated by the extended Debye-Hückel approximation given by Meier, ${ }^{42}$

Acknowledgment. We thank the Netherlands Technology Foundation (STW), Technical Science Branch of the Netherlands Organization for Advanced and Pure Research (NWO) for their financial support. 